\title{
Miljøprinsipper og strategiske beslutninger - reform av norsk lakseoppdrett
}

Professor Ole Kristian Fauchald*

\section{Innhold}

Miljøprinsipper og strategiske beslutninger - reform av norsk lakseoppdrett ........................ 1

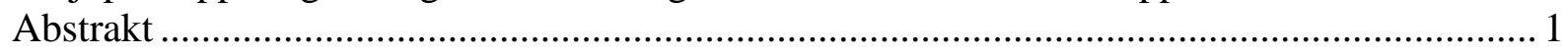

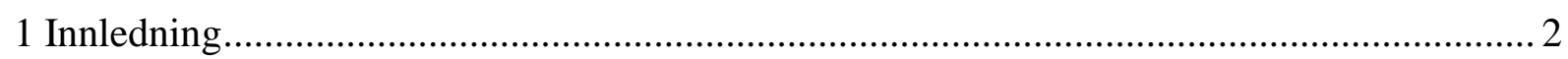

2 Prinsippet om $\varnothing$ kosystembasert forvaltning og føre var prinsippet.................................. 4

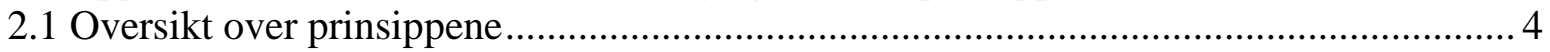

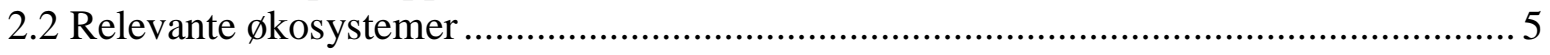

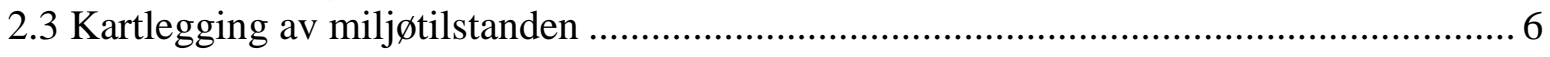

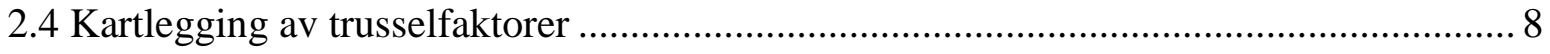

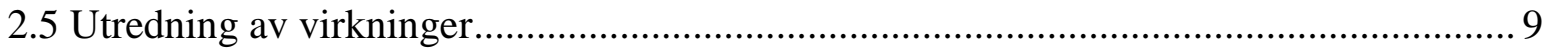

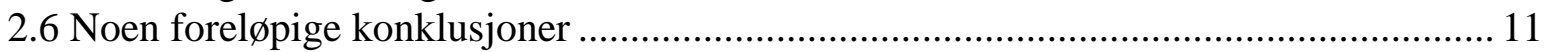

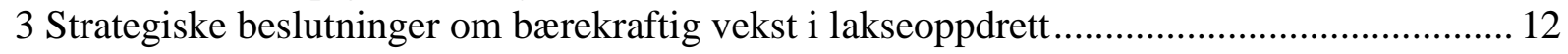

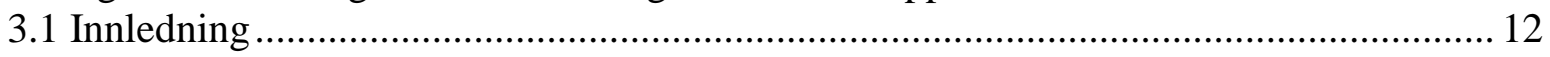

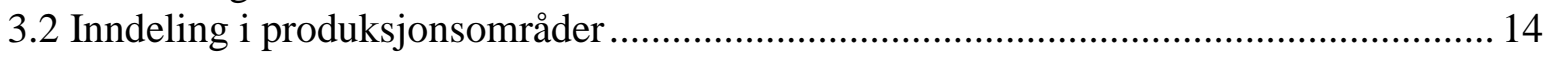

3.3 Lakselus som kriterium for produksjonsjustering ............................................. 18

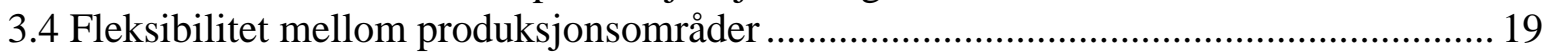

4 Miljørettsprinsippene - nyttige verktøy eller utopiske mål? ............................................... 22

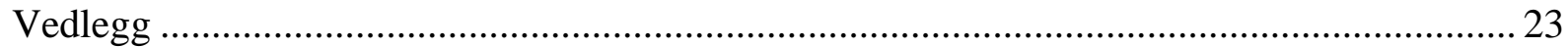

\begin{abstract}
Abstrakt
Lakseoppdrett har på kort tid blitt Norges nest største næring. Det har vært rettet kritikk mot næringen basert på negative miljøvirkninger i kystområdene. Artikkelen drøfter en reform igangsatt i 2017 med mål om bærekraftig vekst i næringen. Den drøfter om virkemidler for å håndtere miljøvirkningene har hatt tilsiktede effekter, og hvordan det kan oppnås bedre virkemiddelbruk. I artikkelen benyttes reformen for å belyse bredere spørsmål om gjennomføringen av to miljørettslige prinsipper - føre var prinsippet og prinsippet om $\varnothing$ kosystembasert forvaltning. Videre diskuteres problemstillinger om plikt, evne og vilje til å utrede konsekvenser av tre strategiske beslutninger - inndeling av kysten i tretten produksjonsområder, å gjøre justering av tillatt produksjonsmengde avhengig av forekomst av lakselus i produksjonsområdene, og å $\varnothing \mathrm{ke}$ oppdretternes fleksibilitet til å flytte produksjon mellom produksjonsområdene. Til tross for at regelverket og politiske føringer tilsier at vedtak skal baseres på vitenskapelige utredninger og miljøhensyn, finner artikkelen at forvaltningsregimet innebærer at næringshensyn og politiske prioriteringer dominerer. Blant hovedutfordringene som påpekes er at regelverket og forvaltningspraksis har blitt så komplekst at det er har blitt svært vanskelig for utenforstående å skaffe seg oversikt over mulige konsekvenser av vedtak, samt at institusjonell fragmentering gjør at miljøhensyn anses som irrelevante i sentrale beslutningsprosesser.
\end{abstract}

Nøkkelord: Akvakultur, laks, miljøprinsipp, konsekvensutredning, bærekraft, virkemiddel, økosystem, næringsreform

\footnotetext{
* Artikkelen er del av forskningsprosjektet GreenlightSIGN finansiert av Norges forskningsråd ved Fridtjof Nansens Institutt. Jeg takker Irja Vormedal, Erling Hjelmeng og to anonyme fagfeller for nyttige kommentarer.
} 


\section{Innledning}

Utvikling av overvåkningsverktøy og informasjonsteknologi gjør at tilgang til informasjon om naturressurser og evnen til å analysere slik informasjon er sterkt $\varnothing$ kende. Dette medfører muligheter og utfordringer for beslutningsprosesser om forvaltning av naturressursene. På den ene side muliggjør utviklingen at vi får mer kunnskap om konsekvenser av beslutningene, og på den annen side kan det lede til beslutningsvegring i påvente av mer informasjon eller fordi informasjonen ikke gir noe entydig svar.

Vi har lenge kunnet observere slike spenninger innen miljøretten, der det over flere tiår har vært argumentert for et «paradigmeskift» som vil innebære at miljøkonsekvenser skal få en langt mer grunnleggende stilling i beslutningsprosessene. ${ }^{1}$ Et sentralt eksempel finnes i regelverk om utredning av miljøkonsekvenser. Der har det tradisjonelt vært detaljerte og strenge krav om utredning ved beslutninger som har begrensende virkninger i tid og rom (konkrete beslutninger), og ingen eller mindre strenge krav for generelle beslutninger der virkningene vanskelig kan avgrenses i tid og rom (strategiske beslutninger). ${ }^{2}$ Dette reflekterer et mer generelt fenomen om svake rettslige krav til ${ }^{3}$ og svakt utviklet metodikk for ${ }^{4}$ utredning av strategiske beslutninger som potensielt har alvorlige kumulative og langsiktige miljøvirkninger. ${ }^{5}$

På bakgrunn av dette skal denne artikkelen drøfte gjennomføringen av to mye diskuterte prinsipper i miljøretten - prinsippet om økosystembasert forvaltning og føre var prinsippet. ${ }^{6}$ Dette er helt sentrale prinsipper for utredning av strategiske beslutningers miljøkonsekvenser og bruken av utredningene $\mathrm{i}$ videre beslutningsprosesser. I tillegg til en generell diskusjon av prinsippene (del 2), skal det unders $\varnothing$ kes hvordan prinsippene ble brukt og kunne vært brukt ved strategiske beslutninger for å legge til rette for «bærekraftig vekst» i norsk lakseoppdrett (del 3).

Det er flere grunner til at norsk lakseoppdrett er særlig interessant som en «case»-studie. Fra et økonomisk perspektiv er næringen sentral for å oppfylle mål om bærekraftig næringsutvikling, sysselsetting, distriktsbosetting og handelsbalanse med utlandet. Fra et miljøperspektiv er næringen avhengig av kystøkosystemer der de norske forvaltningssystemene fremdeles er i støpeskjeen, det foreligger begrenset $\varnothing$ kologisk kunnskap særlig for det marine miljøet, det er betydelige $\varnothing$ kologiske og $\emptyset$ konomiske verdier, samt at det er sterke interessekonflikter. Fra et internasjonalt perspektiv har næringsaktørene betydelige finansielle ressurser, omfattende tilstedeværelse $\mathrm{i}$ andre land og stor innsats

\footnotetext{
${ }^{1}$ Se eksempelvis S. Westerlund, «Rätt och riktig rättsvetenskap», Nordisk Miljörättslig Tidskrift, 2010:1 s. 3-22 med videre referanser, særlig til svensk litteratur. I de senere år har dette også gitt seg utslag i en diskusjon om en ny geologisk tidsalder - anthropocen - og hvilke konsekvenser dette har for beslutningsprosesser, se eksempelvis N. Hammerschlag m.fl., «Ecosystem Function and Services of Aquatic Predators in the Anthropocene», Trends in Ecology \& Evolution, vol. 34(4) (2019) s. 369-383.

${ }^{2}$ Dette kan illustreres ved utviklingen av konsekvensutredningsregelverket, som i flere tiår fokuserte på utredning av konsekvensene av konkrete prosjekter og kun i senere år har tatt opp i seg konsekvensutredning av planer og programmer, se eksempelvis A. Tesli og M. Lund-Iversen, «Norsk KU-historie», i F. Holth og N. K. Winge (red.) Konsekvensutredninger. Rettsregler, praksis og samfunnsvirkninger, Universitetsforlaget, $2014, \mathrm{~s}$. 54-84, og S. E. Schütz, «Internasjonale og EØS-rettslige perspektiv», ibid. s. 85-123.

${ }^{3}$ For norsk regelverk er spørsmål om utredningskrav til strategiske beslutninger drøftet i O. K. Fauchald, «Plikt til å utrede miljøkonsekvenser av lovgivning», i H. C. Bugge, H. Indreberg, A. Syse og A. Tverberg (red.), Lov, liv og lare. Inge Lorange Backer $70 \AA$ Ar , Universitetsforlaget, 2016, s. 187-200.

${ }^{4}$ Se eksempelvis M. Lund-Iversen og K.B. Stokke, «Tilpasning av KU til plannivået», i Holth \& Winge fn 2 s. $131-134$.

${ }^{5}$ Se eksempelvis drøftelsen av «sumvirkninger» i N. K. Winge, Kampen om arealene: Rettslige styringsmidler for en helhetlig utmarksforvaltning, Universitetsforlaget, 2013, s. 74-84.

${ }^{6}$ Temaet har tidligere blitt drøftet i relasjon til forvaltning av norske havområder i I. U. Jakobsen og T. Henriksen, «Prinsippene om føre var og økosystemtilnærming - hvilken betydning har lovfestingen for marin ressursforvaltning», i I. L. Backer, O. K. Fauchald og C. Voigt (red.), Pro Natura: Festskrift til Hans Christian Bugge, Universitetsforlaget, 2012, s. 170-188, s. 227-248. Se også og E. J. Hollo, «Kust och marin miljö i Östersjöregionen - ett ekologiskt rättssystem?», i Bugge, m.fl. fn 3 s. 291-302, med særlig fokus på integrert kystsoneplanlegging.
} 
på forskning og utvikling. ${ }^{7}$ Disse aspektene ved næringen er relativt nye og er resultat av en sterk vekst i næringen siden årtusenskiftet (figur 1).

Figur 1: Produksjonsmengde og salgsverdi av norsk oppdrettslaks 1994-2018

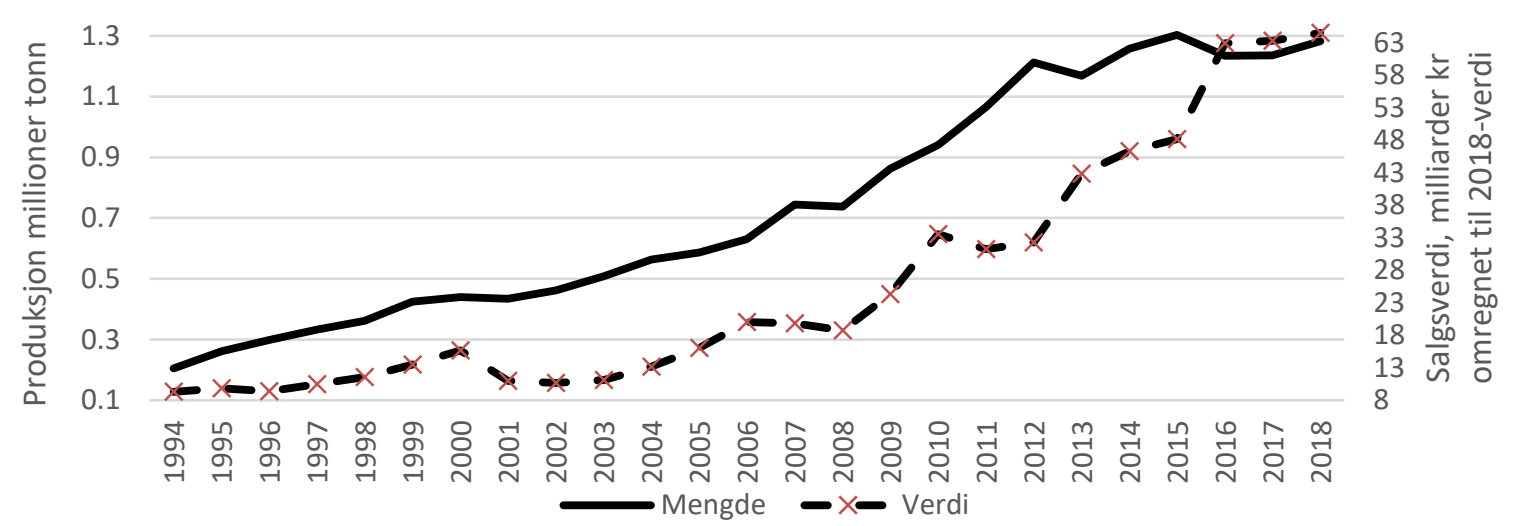

Figur 1 viser at veksten i næringen har vært relativt jevn siden 1994. Etter en innledende oppbyggingsfase (1970-1994) kan vi skille mellom fire perioder: 1) Relativt betydelig produksjonsvekst og uendret verdi (1994-2004), 2) Økt produksjonsvekst og svært betydelig og jevn verdiøkning (20052012), 3) Stagnasjon i produksjon kombinert med fortsatt betydelig verdiøkning (2013-2016), ${ }^{9}$ og 4) Stagnasjon i både produksjon og verdiøkning (fra 2016). Det er liten tvil om at stagnasjonen i de to siste periodene har vært viktig for utviklingen av et nytt forvaltningsregime. Det er bred enighet om at en sentral årsak til stagnasjonen har vært forekomst av lakselus som innebærer produksjonstap og negative miljøkonsekvenser. ${ }^{10}$

Som ledd i analysen av prinsippene og beslutningsprosessene, skal vi analysere tre strategiske beslutninger som har utgjort kjerneelementer i det nye forvaltningsregimet: Inndelingen av Norges kyst i 13 produksjonsområder, valg av lakselus som miljøindikator for produksjonsvekst og graden av fleksibilitet i lokalisering av produksjonen. Artikkelen analyserer hvordan prinsippet om $\varnothing$ kosystembasert forvaltning og føre var prinsippet har vært og kunne ha vært ivaretatt. Reformen ble utarbeidet i nært samarbeid mellom forvaltningsorganer og naturvitenskapelige forskningsmiljøer, og forskningsmiljøene er gitt nøkkelroller i gjennomføringen av reformen. Studien av reformprosessen og rollen til de naturvitenskapelige forskningsmiljøene danner utgangspunktet for en generell diskusjon av de to prinsippene og hvordan de kan gjennomføres, se del 4.

\footnotetext{
${ }^{7}$ Se eksempelvis Meld. St. 16 (2014-2015) kap. 5 og 14, P. B. Sørdahl m.fl., «Hvordan planlegges kystsonen? Kartlegging av gjeldende planpraksis etter plan- og bygningsloven i sjøområdene», Nofima rapport 15/2017, s. 6-11, I. Vormedal, M. L. Larsen og K. H. Flåm, «Grønn vekst i blå næring? Miljørettet innovasjon i norsk lakseoppdrett», FNI Rapport 3/2019, og MOWI, Salmon Farming Industy Handbook, 2019, kap. 7.

${ }^{8}$ Basert på statistikk fra Fiskeridirektoratet, se https://www.fiskeridir.no/Akvakultur/Statistikkakvakultur/Akvakulturstatistikk-tidsserier/Laks-regnbueoerret-og-oerret Til sammenligning hadde tilsvarende akvakultur i Danmark en produksjon på 13848 tonn ørret i 2017, i Finland en produksjon på 11914 tonn ørret i 2018, på Island en produksjon på 13448 tonn laks i 2018 og i Sverige en produksjon på 2870 tonn $\emptyset$ rret i 2018. Av disse er det bare Island som har hatt en $\emptyset$ kende trend i produksjonen de senere år.

${ }^{9}$ For en analyse av tildelingsrundene mellom 2002 og 2013, se E. Mikkelsen, K. M. Karlsen, R. Robertsen og B. Hersoug, «Skiftende vindretning. Særlige hensyn for tildeling av tillatelser til lakseoppdrett», Nofima, Rapport 26/2018. For en redegjørelse for konteksten til produksjonsutviklingen, se I. Vormedal, «Corporate Strategies in Environmental Governance: Marine harvest and regulatory change for sustainable aquaculture», Environmental Policy and Governance, vol. 27, 2017, s. 51-53.

${ }^{10}$ Se E. Mikkelsen m.fl., 2018 ibid., og B. Hersoug, «The greening of Norwegian salmon production», Maritime Studies, vol. 14, artikkel 16, 2015.
} 


\section{Prinsippet om økosystembasert forvaltning og føre var prinsippet}

\subsection{Oversikt over prinsippene}

Internasjonalt har prinsippet om $\phi$ kosystembasert forvaltning bred oppslutning, men dets juridiske status og innhold er fremdeles uklart. ${ }^{11}$ Prinsippets status og innhold varierer tilsynelatende mye mellom og innen nasjonale rettssystemer. I det seneste tiåret har prinsippet blitt fulgt opp gjennom initiativer for å definere og verdsette $\varnothing$ kosystemtjenester og å inkludere slike verdier i beslutningsprosesser. ${ }^{12}$

Føre var prinsippet har i stor grad vært omstridt internasjonalt. ${ }^{13}$ Mye av grunnen er prinsippets konsekvenser for internasjonal handel, særlig som følge av at det har begrunnet forbud mot skadelige produkter, produksjonsprosesser og tjenester. ${ }^{14}$ Selv blant land der prinsippet har bred oppslutning, er det betydelige ulikheter i hvordan det følges opp i praksis, særlig i forbindelse med strategiske beslutninger. ${ }^{15}$

I norsk rett er begge prinsippene tatt inn i naturmangfoldloven (nml, $2009 \mathrm{nr}$. 100). De skal anvendes innenfor alle relevante næringer på både konkrete og strategiske beslutninger. ${ }^{16}$ Prinsippet om $\emptyset$ kosystembasert forvaltning ( $(10)$ er generelt formulert: «En påvirkning av et $\varnothing$ kosystem skal vurderes ut fra den samlede belastning som $\emptyset$ kosystemet er eller vil bli utsatt for.» Ettersom både $\varnothing$ kosystemer og samlet belastning er vanskelige å avgrense i tid og rom, vil det ofte være stor usikkerhet ved anvendelsen av prinsippet. Hvordan denne og annen usikkerhet skal håndteres er angitt ved føre var prinsippet (§ 9):

Når det treffes en beslutning uten at det foreligger tilstrekkelig kunnskap om hvilke virkninger den kan ha for naturmiljøet, skal det tas sikte på å unngå mulig vesentlig skade på naturmangfoldet. Foreligger en risiko for alvorlig eller irreversibel skade på naturmangfoldet, skal ikke mangel på kunnskap brukes som begrunnelse for å utsette eller unnlate å treffe forvaltningstiltak.

Prinsippene kan anvendes der beslutninger angår to ulike objekter. For det første kan de anvendes på elementer i naturen - for eksempel beslutninger om et verneområde eller om arter som utnyttes gjennom jakt eller fiske. Her vil typisk hensikten være å sikre at naturelementene forvaltes i tråd med langsiktige mål for $\varnothing$ kosystemene. For det andre kan de anvendes på beslutninger om menneskelige aktiviteter - for eksempel beslutninger om hvordan næringsaktører skal opptre for å oppnå langsiktig økologisk bærekraft i en næringssektor. I denne artikkelen står det sistnevnte i fokus - hvordan prinsippene (kan) anvendes overfor oppdrettsnæringen.

Prinsippene må forstås i sammenheng med de generelle utredningskravene i nml $\S 8$. Her er det fastlagt en plikt til å basere beslutninger på «vitenskapelig kunnskap», men med et forbehold om at «[k]ravet til kunnskapsgrunnlaget skal stå i et rimelig forhold til sakens karakter og risiko for skade på naturmangfoldet.» Samlet reiser prinsippene og kunnskapskravet fire hovedspørsmål som skal diskuteres nedenfor:

\footnotetext{
${ }^{11}$ Se Malawi-prinsippene utarbeidet under konvensjonen om biologisk mangfold (CBD) (COP decision V/6 og SBSTTA recommendation V/10 (2000)), tiltak for implementering (COP decision VII/11 (2004) og IX/7 (2008)) og https://www.cbd.int/ecosystem/background.shtml

${ }^{12}$ Initiativene tar utgangspunkt i CBD artikkel 11, 20 og 21 (COP decision IX/11 (2008)) og ble etter hvert forankret i rapporter om «the economics of ecosystems and biodiversity» (TEEB), utarbeidet på initiativ fra 13 miljøministre i 2007, se http://www.teebweb.org/

${ }^{13}$ Se prinsipp 15 i Rio-erklæringen som bruker begrepet «approach» i stedet for «principle».

${ }^{14}$ Eksempler er sakene om hormonbehandlet kjøtt og genmodifiserte organismer som har versert i GATT og WTO over flere tiår, se sakene DS26, DS48, DS320 og DS321 (hormonsaken) og DS290, DS291 og DS 292 (GMO-saken), https://www.wto.org/english/tratop_e/dispu_e/dispu_e.htm

${ }^{15}$ For en diskusjon av prinsippets gjennomføring i Norden, se N. de Sadeleer (red.), Implementing the Precautionary Principle. Approaches from the Nordic Countries, EU and USA, Earthscan, 2007.

${ }^{16}$ Prinsippene skal anvendes ved utforming av regelverk og $\emptyset$ konomiske virkemidler, ettersom slike beslutninger er «utøvelse av offentlig myndighet» etter nml § 7, se Ot.prp.nr. 52 (2008-2009) Om lov om forvaltning av naturens mangfold s. 102, 104, 378-379 og 381-382. Dette er også lagt til grunn i KLDs veileder, se Klima- og miljødepartementet, Naturmangfoldloven kapittel II. Alminnelige bestemmelser om bærekraftig bruk (2016) s. 17.
} 
1. Hvordan kan relevante $\varnothing$ kosystem avgrenses (punkt 2.2)?

2. Hvilken kunnskap om økosystemenes tilstand er nødvendig (punkt 2.3)?

3. Hvilken informasjon om menneskelige aktiviteter og andre faktorer som påvirker $\emptyset$ kosystemene er nødvendig (punkt 2.4)?

4. Hvordan skal man vurdere mulige konsekvenser av beslutninger (punkt 2.5)?

I en typisk beslutningsprosess vil de tre første spørsmålene inngå i kartleggingen av hva som er den «økologiske tilstanden» $(\mathrm{nml} \S 3(\mathrm{~s})),{ }^{17}$ mens det siste angår vurderinger av mulige fremtidsscenarier.

\subsection{Relevante økosystemer}

I nml § 3(t) defineres et økosystem som «et mer eller mindre velavgrenset og ensartet natursystem der samfunn av planter, dyr, sopp og mikroorganismer fungerer i samspill innbyrdes og med det ikkelevende miljøet». ${ }^{18}$ Definisjonen forutsetter analyser av sammenhengen mellom natursystemer, og er derfor naturvitenskapelig basert. Den åpner for at det kan være store variasjoner i hva som anses som $\emptyset$ kosystemer. Noe som er ansett som ett $\varnothing$ kosystem i en analyse kan gjerne anses som en kombinasjon av mange $\varnothing$ kosystemer i en annen analyse. Begrepet er derfor i stor grad kontekstavhengig.

Økosystembegrepet er nært beslektet med to andre begreper i loven; «naturtype» og « $\varnothing$ kologisk funksjonsområde». En naturtype er definert som en «ensartet type natur som omfatter alle levende organismer og de miljøfaktorene som virker der» $(\mathrm{nml} \S 3(\mathrm{j}))$. Det er utført et omfattende arbeide med å klassifisere og kartlegge naturtyper i Europa. ${ }^{19}$ I Norge har dette arbeidet foreløpig ikke kommet så langt for marine som for terrestriske naturtyper. ${ }^{20}$

Et $\varnothing$ kologisk funksjonsområde er definert som et «område - med avgrensing som kan endre seg over tid - som oppfyller en økologisk funksjon for en art» (nml § 3(r)). Dette er i hovedsak det samme som «habitat» og «biotop». Sistnevnte begreper står sentralt der verneområder etableres for vern av arter (nml §§ 24 første ledd (b) og 38) og i EUs klassifikasjonssystem basert på habitatdirektivet.

Økosystembegrepet kombinerer «naturtyper» og «økologiske funksjonsområder» ved å være basert på samspillet mellom levende organismer, og mellom organismene og det ikke-levende miljøet. Det er ikke foretatt noen systematisk klassifikasjon av økosystemer i Norge. Det er etablert et fleksibelt mål om at «økosystemers funksjoner, struktur og produktivitet ivaretas så langt det anses rimelig» (nml § 4). Målet for naturtyper er mer forpliktende: «[M] angfoldet av naturtyper ivaretas innenfor deres naturlige utbredelsesområde og med det artsmangfoldet og de økologiske prosessene som kjennetegner den enkelte naturtype» ( $\mathrm{nml} \S 4)$.

Lokalisering av oppdrettsanlegg baseres på en rekke momenter. Særlig viktige er temperatur, vannkvalitet, forekomst av sykdommer og vanngjennomstrømning. Dette medfører at det er relativt begrensede arealer som er egnet for oppdrett. ${ }^{21}$ Til tross for dette, vil det være vanskelig å avgjøre hvilke $\emptyset$ kosystemer som påvirkes av strategiske beslutninger innen oppdrettssektoren. Utslipp fra lakseoppdrett påvirker et større eller mindre område rundt oppdrettsanlegget. Påvirkningssonen varierer til dels betydelig med anleggets størrelse, plassering, strøm og bølgeeksponering. ${ }^{22}$ Anleggene plasseres helst i

\footnotetext{
${ }^{17} \emptyset$ kologisk tilstand omfatter «status og utvikling for funksjoner, struktur og produktivitet i en naturtypes lokaliteter sett i lys av aktuelle påvirkningsfaktorer».

${ }^{18}$ Se også St.meld. nr. 12 (2001-2002) s. 16: «Økosystemtilnærming til havforvaltning er en integrert forvaltning av menneskelige aktiviteter basert på økosystemenes dynamikk. Målsetningen er å oppnå bærekraftig bruk av ressurser og goder fra økosystemene og opprettholde deres struktur, virkemåte og produktivitet.»

${ }^{19}$ Direktiv 92/43/EEC, 21. mai 1992. EUs klassifikasjon skiller seg følgelig fra Norges naturtypeklassifikasjon. Se også Convention on the Conservation of European Wildlife and Natural Habitats (1979) artikkel 4 og European Nature Information System (EUNIS) https://eunis.eea.europa.eu/habitats-code-browser.jsp

${ }^{20}$ Se R. Halvorsen, «NiN natursystem-nivået - oversettelse fra NiN versjon $1.0 »$ og «Norsk rødliste for naturtyper 2011 til NiN versjon 2.0», Natur i Norge, Artikkel 4 (versjon 2.0.4, 2015), vedlegg 3, s. 81 ff. og R. Halvorsen, A. Bryn og L. Erikstad, «NiNs systemkjerne - teori, prinsipper og inndelingskriterier», Natur $i$ Norge, Artikkel 1 (versjon 2.1.0, 2016), s. 31-49.

${ }^{21}$ Fiskeri- og kystdepartementet, Effektiv og barekraftig arealbruk i havbruksnaringen - areal til begjar, rapport fra et ekspertutvalg, 2011 kap. 3 og 8.

${ }^{22}$ Havforskningsinstituttet, «Risikorapport norsk fiskeoppdrett 2018», Fisken og havet, særnummer 1-2018 s. 112.
} 
områder med mye strøm og lite bølgeeksponering. Videre finnes det tiltak som tar sikte på å bedre fiskehelsen i lokaliteten, men som innebærer belastning av økosystemer som befinner seg lenger unna lokaliteten. Eksempler er bruk av brønnbåter til avlusning der utslipp får virkninger utenfor anleggets normale påvirkningssone, ${ }^{23}$ og frislipp av store mengder levende leppefisk til avlusning. Det kan følgelig være store variasjoner i størrelsen på påvirkningssonene rundt oppdrettslokalitetene og i graden av påvirkning i sonene. Disse påvirkningssonene vil være utgangspunktet for vurdering av $\emptyset$ kosystemvirkninger.

Videre har lakseoppdrett negativ påvirkning på vill laksefisk (laks, sjøørret og sjørøye), særlig som følge av sykdomsspredning (inklusive lakselus) og genetisk påvirkning fra rømt oppdrettslaks. ${ }^{24}$ Til tross for en rekke tiltak, har man så langt ikke klart å løse dette problemet. ${ }^{25}$ Ettersom Norge har klart flest bestander av og har det største gyteområdet for nord-øst atlantisk villaks, har Norge også et særlig ansvar for å sikre bærekraftig forvaltning av denne arten. ${ }^{26}$ Villaks er en del av mange forskjellige $\emptyset$ kosystemer som følge av sitt migrasjonsmønster. Tilsvarende gjelder for sjøørret og sjørøye, men disse oppholder seg i mer avgrensede kystområder. ${ }^{27}$ Virkningene av lakseoppdrett for vill laksefisk tilsier at det kan være behov for å vurdere фkosystemeffekter i elver og fjerntliggende havområder. For havområdene vil det imidlertid være svært utfordrende å påvise årsakssammenheng mellom norsk oppdrett og økosystemendringer. Slike fjerntliggende $\varnothing$ kosystemer kan likevel være relevante når det fattes strategiske beslutninger med store virkninger for omfang og lokalisering av lakseoppdrett.

Endelig kan lakseoppdrett mer indirekte påvirke økosystemer som følge av innsatsfaktorer i produksjonen. Mens virkninger som følge av produksjon av fôr, kjemikalier og medisiner eventuelt bare kan vurderes på et overordnet nivå, har bruk av leppefisk mer direkte og geografisk avgrensede virkninger. Registreringer av bruk av leppefisk viser at det i gjennomsnitt har vært levert over 20 millioner levende individer per år. ${ }^{28}$ Det finnes bare i helt ubetydelig grad oppdrett av leppefisk. Oppdrettsnæringens bruk av leppefisk har følgelig betydning for forekomst av leppefisk i ulike $\emptyset$ kosystemer langs det meste av norskekysten, og virkninger for disse $\varnothing$ kosystemene vil være relevant.

\subsection{Kartlegging av miljøtilstanden}

Alle norske forvaltningsorganer har en plikt til å «på et overordnet nivå ha miljøinformasjon som er relevant i forhold til sine egne ansvarsområder og funksjoner» (miljøinformasjonsloven, $2003 \mathrm{nr} .31$, $\S 8)$. Når det fattes beslutninger skal myndighetene «så langt det er rimelig» bygge på vitenskapelig kunnskap om naturtypers økologiske tilstand. Hva som er rimelig, skal avgjøres på basis av «sakens karakter og risiko for skade på naturmangfoldet» (nml § 8). Ansvaret for kartlegging av miljøtilstanden i økosystemene som påvirkes av lakseoppdrett er delt mellom Klima- og miljødepartementet og

\footnotetext{
${ }^{23}$ Se eksempelvis NRKs nyhetsoppslag 13. august 2018 om praksis ved utslipp av avlusningsmiddel, https://www.nrk.no/trondelag/fiskarlaget-krever-at-myndighetene-griper-inn-mot-ulovlig-dumping-avlusemidler-1.14105125

${ }^{24}$ Vitenskapelig råd for lakeforvaltning, Klassifisering av tilstand i norske laksebestander 2010-2014, Temarapport nr. 6 (2018) s. 4: «Den største negative påvirkningen ut fra antall berørte bestander, uavhengig av størrelsen på effekten, var rømt oppdrettslaks, fulgt av lakselus, vannkraftregulering og arealinngrep. Ut fra størrelsen på effekten i form av redusert bestandsstørrelse, var det de samme fire påvirkningene som var de største, men da med lakselus med størst negativ effekt, fulgt av rømt oppdrettslaks, vannkraftregulering og arealinngrep.» Se også Vitenskapelig råd for lakeforvaltning, Klassifisering av tilstanden til 430 sjøørretbestander, Temarapport nr. 7 (2019) s. 17 og 28-30 som kartlegger økt dødelighet som følge av menneskelig aktivitet, der forekomst av lakselus som følge av oppdrettsvirksomhet står sentralt.

${ }^{25}$ Vitenskapelig råd for lakseforvaltning, Status for norske laksebestander i 2018, Rapport nr. 11, 2018.

${ }^{26}$ Report of the ICES Advisory Committee 6 May 2016, NASCO Council dok. nr. CNL(16)9. Se også Convention for the Conservation of Salmon in the North Atlantic Ocean (konvensjon til vern av laks i det nordlige Atlanterhavet) og tilhørende regelverk.

${ }^{27}$ Se Vitenskapelig råd for lakseforvaltning, Klassifisering av tilstanden til 430 sjøørretbestander, Temarapport nr. 7, 2019.

${ }^{28} \mathrm{Se}$ https://www.fiskeridir.no/Yrkesfiske/Statistikk-yrkesfiske/Fangst-og-kvoter/Landa-fangst-av-leppefisk og https://www.imr.no/hi/temasider/arter/leppefisk
} 
Miljødirektoratet (miljøtilstanden generelt og vill laksefisk), ${ }^{29}$ Nærings- og fiskeridepartementet og Fiskeridirektoratet (fiskeri og havbruk), samt Olje- og energidepartementet og Norges vassdrags- og energidirektorat (elvene).

Kunnskap om status og utvikling av økosystemene finnes på et overordnet nivå i Naturindeksen. ${ }^{30}$ Indeksen deler landet inn i ni hovedøkosystemer. For kystøkosystemene kartlegger Naturindeksen miljøtilstanden i vannsøylen (pelagisk) og på havbunnen i fem geografiske områder (Nord-Norge, MidtNorge, Vestlandet, Sørlandet og Østlandet). Som referanse brukes en tilstand der naturen er intakt med stedegent biologisk mangfold. Tilstanden i kystøkosystemene måles ved hjelp av 74 indikatorer, inklusive et utvalg nøkkelindikatorer, hvorav 37 er tilknyttet henholdsvis havbunnen og vannsøylen. ${ }^{31}$ Den minste geografiske enheten i indeksen er kommuner, men mange indikatorer mangler data på dette nivået. Så langt er økosystemenes tilstand beregnet for årene 1990, 2000, 2010 og 2014. Generelt viser Naturindeksen en relativt stabil kvalitet for bunnøkosystemene, og ganske stor variasjon for økosystemene i vannsøylen. Økosystemene har generelt hatt dårligere tilstand på bunnen enn i vannsøylen. Det er høyere usikkerhet for 2014 enn for tidligere vurderinger på grunn av manglende data, særlig for fiskebestandene og for fjordene. ${ }^{32}$ I vurderingen av vesentlige påvirkningsfaktorer påpekes det at: «På Vestlandet og nordover er det fiskeriene og høy tetthet av fiskeoppdrett som utgjør de viktigste påvirkningsfaktorene.» For disse områdene har det vært markert forverring av tilstanden siden $2010 .{ }^{33}$

I det vesentlige blir informasjon om $\varnothing$ kosystemers tilstand fremskaffet av tre norske forskningsmiljøer. Ansvarsdelingen mellom forvaltningsorganene er i stor grad reflektert i organiseringen av forskningsmiljøene. Havforskningsinstituttet er sentralt for kartlegging av havøkosystemene og kystområdene og er organisert som et forvaltningsorgan under Nærings- og fiskeridepartementet. ${ }^{34}$ Norsk institutt for naturforskning har en sentral rolle i forskningen på vill laksefisk og ferskvannsøkosystemer, og er en uavhengig stiftelse som får basisbevilgning fra Norges forskningsråd og har betydelige oppdrag fra miljøforvaltningen. ${ }^{35}$ Norsk institutt for vannforskning er også organisert som en uavhengig stiftelse med oppdrag for miljøforvaltningen, men i større grad enn de andre forskningsinstituttene har de konsulentoppdrag, inklusive mange oppdrag fra energimyndighetene.$^{36}$ Statlig forvaltning har følgelig store muligheter for å styre forskningen for å sikre tilstrekkelig kunnskap om økosystemene, dels direkte gjennom instrukser, dels gjennom bevilgninger til Norges forskningsråd, og dels gjennom oppdragsforskning. I de senere år har det vært stor forskningsaktivitet på villaks. ${ }^{37}$ Det er samlet inn langt mindre informasjon om andre arter og naturtyper som påvirkes av lakseoppdrett. ${ }^{38}$

\footnotetext{
${ }^{29}$ Av spesiell relevans er miljømyndighetenes forvaltningsansvar for vill laksefisk (se forskrift for kvalitetsnorm for ville bestander av atlantisk laks, FOR-2013-09-20-1109) og for gjennomføring av forskrift om rammer for vannforvaltning (FOR-2006-12-15-1446).

${ }^{30} \mathrm{Se}$ http://www.naturindeks.no

${ }^{31}$ E. Framstad (red.), Naturindeks for Norge 2015. Tilstand og utvikling for biologisk mangfold, s. 51-53. For detaljer angående indikatorer, se B. Pedersen og S. Nybø (red.), Naturindeks for Norge 2015. Økologisk rammeverk, beregningsmetoder, datalagring og nettbasert formidling, NINA Rapport 1130 (2015) vedlegg 1. ${ }^{32}$ Framstad ibid. s. 53.

${ }^{33}$ Ibid. s. 54 og 55.

${ }^{34}$ Havforskningsinstituttet instrueres gjennom hovedinstruks, årlige tildelingsbrev, etterfølgende tillegg til brevene og halvårlige styringsmøter med departementet, se Nærings- og fiskeridepartementet, Hovedinstruks for styringen av Havforskningsinstituttet (2018) punkt 8: «Havforskningsinstituttet skal ha en fri og uavhengig rolle i alle faglige spørsmål. Havforskningsinstituttets forskning og forskningsoppdrag finansiert av departementet skal ha et forvaltningsrettet formål og departementet fastsetter hvilke områder instituttet skal forske, hente inn data og gi råd, innenfor. ... Eksternt finansiert aktivitet skal være innenfor rammen av instituttets formål og skal støtte opp om de faglige prioriteringene i de årlige tildelingsbrevene.»

${ }^{35}$ Se Norsk institutt for naturforskning, Årsrapport 2017, s. 5.

${ }^{36}$ Se NIVA, Årsrapport for 2017.

${ }^{37}$ Dette er et ledd i oppfølgningen av kvalitetsnormen for villaks, se $\mathrm{nml} \S 13 \mathrm{og} \mathrm{fn} 29$. Forskning publiseres og oppsummeres i rapporter fra Vitenskapelig råd for lakseforvaltning.

${ }^{38}$ Effektiv og bærekraftig arealbruk fn 21 s. 186. Eksempelvis var Nærings- og fiskeridepartementets bevilgning til Norges forskningsråd for 2018 fordelt som følger: 1,37 milliarder til «økt konkurranseevne i nytt og
} 
Utgangspunktet er at beslutninger som et minimum må baseres på foreliggende informasjon om $\emptyset$ kosystemenes tilstand, særlig informasjon som fremgår av offentlige databaser eller av publisert forskning. Det må også foretas bearbeiding av tilgjengelige data som kan bidra til å vurdere tilstanden. I tillegg kan det være en plikt til å innhente nye data. Plikten til innhenting av nye data og bearbeiding av data er begrenset til det som med rimelighet kan kreves, jf. nml $\S 8$. Sentrale faktorer for rimelighetsvurderingen er hva slags beslutning det er snakk om, karakteristika ved oppdrettsvirksomheten (omfang og lokalisering), karakteristika ved den informasjonen som foreligger (eksempelvis kvaliteten på data) og kostnader ved innsamling og bearbeiding. Grunnloven $\S 112$ annet ledd om rett til kunnskap om naturens tilstand er relevant for rimelighetsvurderingen. Samlet innebærer dette at det må innhentes informasjon om økosystemenes tilstand og funksjoner som kan ha vesentlig betydning for naturens produksjonsevne og mangfold.

\subsection{Kartlegging av trusselfaktorer}

I henhold til nml $\S 10$ må det også foreligge informasjon om den samlede belastning økosystemet utsettes for. Dette innebærer en plikt til å utrede trusselfaktorer. I en veileder fra Klima- og miljødepartementet identifiseres fire trusselkategorier: 1) Det konkrete tiltaket, 2) Andre tiltak av samme art (in casu oppdrettsanlegg), 3) Andre typer tiltak eller inngrep (eksempelvis deponering av gruveavfall) og 4) Andre påvirkningsfaktorer (eksempelvis klimaendringer).$^{39}$ På et generelt nivå har myndighetene og næringen relativt god oversikt over de to første kategoriene. ${ }^{40}$ Dersom vi ser nærmere på kunnskapsstatus og myndighetenes og næringens prioritering av forskning og miljøovervåkning må imidlertid dette bildet nyanseres. I en rapport fra 2016 om kunnskapsstatus og forskningsbehov ble det pekt på store kunnskapsmangler. ${ }^{41}$ Fram til 2015 gikk en svært liten andel av offentlig forskningsfinansiering og næringens egne forskningsmidler til studier av miljøeffekter av lakseoppdrett. ${ }^{42}$ Mens Vormedal finner at næringsaktører har egeninteresser i å håndtere negative konsekvenser, ${ }^{43}$ er det også eksempler på at næringsaktører mangler vilje til å opplyse om slike konsekvenser. ${ }^{44}$

Videre er innsamling av informasjon om de to første trusselfaktorene i stor grad avhengig av hvordan konsekvensutredningsregelverket praktiseres. Når sjøområder settes av til akvakulturformål som ledd i kystsoneplanlegging har det ikke vært vanlig å foreta miljøkonsekvensutredninger etter plan- og bygningsloven (2008 nr. 71, heretter pbl se $§ 11-7 \mathrm{nr} .6) .{ }^{45}$ Ofte vil det være uklart hva som skal utredes, ettersom det er stor variasjon i mulig akvakulturvirksomhet. Dersom det bestemmes at området skal settes av til lakseoppdrett (pbl § 11-11 nr. 7), vil usikkerheten reduseres betydelig. Men fremdeles kan det være stor forskjell på oppdrettsanleggenes størrelse (se figur 4 nedenfor) og driftsform.

eksisterende næringsliv og styrket evne til omstilling i norsk økonomi», 0,73 milliarder til «bedre samspill og kunnskapsoverføring mellom FoU-miljøer og næringsliv», og i overkant av 5 millioner til «annet».

${ }^{39}$ Klima- og miljødepartementet, Naturmangfoldloven kapittel II, fn 16 s. 53-55.

${ }^{40}$ Se årlige risikorapporter for fiskeoppdrett utarbeidet av Havforskningsinstituttet siden 2010, https://www.imr.no/publikasjoner/andre_publikasjoner/risikovurdering_miljovirkninger_av_norsk_fiskeoppdrett /nn-no

${ }^{41}$ V. Husa m.fl., «Effekter av utslipp fra akvakultur på spesielle marine naturtyper, rødlista habitat og arter.» Kunnskapsstatus, Rapport fra Havforskningen nr. 8-2016.

${ }^{42}$ B. Sarpebakken og S. Søyland Ubisch, «Ressursinnsatsen til marin FoU og havbruksforskning i 2015», Nordisk institutt for studier av innovasjon, forskning og utdanning (NIFU) rapport 2017:3. Tabellene 35 og $36 \mathrm{~s}$. 69 viser at en liten andel av offentlig finansiering gikk til miljøeffektstudier. Tabell 37 s. 70 viser at i 2015 gikk bare 1,5\% av næringens forskningsfinansiering til slike formål. Tabellene 47 og $48 \mathrm{~s}$. $73-74$ viser at miljøeffektstudier i perioden 2001-2015 utgjorde 6,9\% av masteravhandlingene og 8,5\% av $\mathrm{PhD}$ avhandlingene innen havbruk.

${ }^{43}$ Se Vormedal fn 9 s. 50-55.

${ }^{44}$ Eksempelvis viser gjenfangststudier at reelt antall rømte oppdrettslaks i perioden 2005 til 2011 var to til fire ganger høyere enn rapporterte tall, se Vitenskapelig råd for lakseforvaltning fn $25 \mathrm{~s} .65$.

${ }^{45}$ Om planpraksis i kystsonen, se Sørdahl m.fl. fn 7 s. 39-47, I. Kvalvik og R. Robertsen, «Inter-municipal coastal zone planning and designation of areas for aquaculture in Norway: A tool for better and more coordinated planning?», Ocean and Coastal Management, vol. 142, 2017, s. 61-70, I. E. Myklebust, «Miljøkrav i saker som gjeld akvakultur», Kart og Plan, 2018 nr. 2, s. 174-187, og I .E. Myklebust, «Akvakultur og det kommunale sjølvstyret», Kart og Plan, 2018 nr. 2 s. 195. 
Ved tildeling av lokaliteter har lakseoppdrettere bare helt unntaksvis blitt pålagt å foreta miljøkonsekvensutredninger. ${ }^{46}$ Det er overlatt til oppdretterne å vurdere om konsekvensutredning er nødvendig, og det er ikke etablert prosedyrer dersom søker mener at slik utredning er un ødvendig. ${ }^{47}$ Som følge av dette har næringens utredninger og miljøovervåkning i realiteten vært begrenset til sjøbunnen umiddelbart under anleggene. Kun unntaksvis blir det pålagt utvidede undersøkelser og overvåkning av bunnorganismer i en større påvirkningssone. ${ }^{48}$ Inntil 2018 hadde myndighetene bare utarbeidet normer for utredning av virkninger for bløtbunn, ${ }^{49}$ en praksis som kan medføre at miljøkvaliteter på hard bunn, eksempelvis korallforekomster, ikke oppdages. ${ }^{50}$

Det at man generelt unnlater å foreta konsekvensutredninger etter pbl ved planvedtak om å avsette områder til oppdrett generelt, er ikke i strid med EØS-regelverket om konsekvensutredning av planer (direktivet 2001/42/EF). ${ }^{51}$ Dersom man setter av området til lakseoppdrett, kan det imidlertid være plikt til konsekvensutredning etter direktivets art. 3. Ved lokalitetsklarering for lakseoppdrett kan det være plikt til konsekvensutredning etter regelverket om konsekvensutredning av tiltak (direktiv 2011/92/EU art. 4(2)). Hvorvidt det foreligger en slik plikt, skal avgjøres av en offentlig myndighet i henhold til en fastsatt prosedyre (art. 4(3) - (6)). De kravene myndighetene stiller til konsekvensutredning i forskriftene under akvakulturloven (2005 nr. 79, heretter akl) oppfyller ikke direktivets krav (art. 5 og 6). Videre er fylkeskommunenes saksbehandling når det ikke kreves utredning etter pbl i strid med prosedyren som kreves i direktivet. ${ }^{52}$ Denne praksisen innebærer at det produseres lite kunnskap om miljøkonsekvensene av lakseoppdrett.

I omtalen av de to siste gruppene av trusselfaktorer - andre typer tiltak eller inngrep og andre påvirkningsfaktorer - angir Klima- og miljødepartementets veileder at det bare vil være nødvendig å kartlegge disse i den grad de kan påvirke det «samme naturmangfold som påvirkes av det aktuelle tiltaket/inngrepet.» ${ }^{53}$ En slik tilnærming er ikke økosystembasert og føre var (nml $\S 9$ og 10). For å være фkosystembasert, må en utredning ta hensyn til de konsekvenser påvirkning av deler av et $\emptyset$ kosystem får for $\emptyset$ kosystemet som helhet. Ut fra føre var prinsippet må det uansett stilles krav til kartlegging av faktorer som med relativt stor grad av sannsynlighet antas å ha direkte og betydelige negative effekter på økosystemet.

\subsection{Utredning av virkninger}

For de strategiske beslutningene som diskuteres i denne artikkelen kommer ikke konsekvensutredningsregelverket i pbl til anvendelse. I tillegg til kravet i $\mathrm{nml} \S 8$, som omtalt over, innebærer Grunnloven $\S 112$ annet ledd utredningsplikt i den grad det er nødvendig for å ivareta retten til bevaring av naturens produksjonsevne og mangfold. Det finnes også miljøkvalitetsnormer av betydning for utredningsplikten, inklusive den generelle normen i $\mathrm{nml} \S 4 \mathrm{om}$ at « $\varnothing$ kosystemers funksjoner, struktur og produktivitet ivaretas så langt det anses rimelig» og mer spesifikke normer i

\footnotetext{
${ }^{46}$ Se O. Andreassen m.fl., «Konsekvensutredninger - verktøy for mer bærekraftig akvakultur», Nofima Rapport 42/2011 og I. E. Myklebust, «Aquaculture law and administration in Norway», i N. Bankes, I. Dahl og D. L. VanderZwaag (red.), Aquaculture Law and Policy: Global, Regional and National Perspectives, Edward Elgar, 2016, s. 344 og 354-357.

${ }^{47}$ Se Klima- og miljødepartementet og Kommunal- og moderniseringsdepartementet, «Veileder: Når skal tiltak i vedlegg II konsekvensutredes?»Vurdering etter $\$ 10$ i forskrift om konsekvensutredninger, Kommentarutgave (2017) og https://www.fiskeridir.no/Akvakultur/Tildeling-og-tillatelser/Konsekvensutredninger

${ }^{48}$ Se Forskrift om tillatelse til akvakultur for laks, ørret og regnbueørret (FOR-2004-12-22-1798) § 36, Forskrift om drift av akvakulturanlegg (FOR-2008-06-17-822) §§ 35 og 36, og

https://fiskeridirektoratet.no/Akvakultur/Drift-og-tilsyn/Overvaaker-miljoepaavirkningen

${ }^{49}$ Fiskeridirektoratet, Årsrapport 2018, s. 37.

${ }^{50}$ Se eksempelvis Miljødirektoratets klagevedtak i sak om tilbaketrekking av forurensningstillatelse til oppdrett ved Husevågøy, datert 14. januar 2020.

${ }^{51}$ EØS-avtalen vedlegg XX nr. 1 a og $1 \mathrm{~g}$.

${ }^{52}$ Norsk praksis harmonerer dårlig med den praksis som følges for eksempel i Danmark, se C. Prip, «Regulation of mariculture in Denmark: What of the legal and environmental space?», Nordisk Miljörättslig Tidskrift 2016:2, s. 89-103.

${ }^{53}$ Klima- og miljødepartementet, Naturmangfoldloven kapittel II, fn 16 s. 56.
} 
vannforskriften, ${ }^{54}$ regelverket om verneområder, ${ }^{55}$ kvalitetsnormen for villaks, ${ }^{56}$ og regelverk om nasjonale laksevassdrag og -fjorder. ${ }^{57}$ Der det er usikkert om $\varnothing$ kosystemtilstanden oppfyller generelle eller spesifikke miljøkvalitetsnormer eller det er høy risiko for at slike normer ikke vil bli oppfylt, må det $\mathrm{i}$ henhold til føre var prinsippet stilles strenge krav til utredningen av beslutningers $\varnothing$ kosystemvirkninger. Desto mer presis en kvalitetsnorm er, desto lettere vil det være å fastlegge om det er høy risiko for at normen ikke vil bli oppfylt.

Utredning av virkningene av en strategisk beslutning vil ha særlig stor usikkerhet dersom det er uavklart hvordan beslutningen påvirker relevante aktiviteter. Eksempelvis vil det være stor usikkerhet knyttet til virkningene av en strategisk beslutning som generelt vil innebære $\varnothing \mathrm{kt}$ produksjon i oppdrettsnæringen, men hvor det er uklart hvor produksjonsøkningen vil finne sted. Dette er en viktig problemstilling for de beslutningene som skal drøftes i del 3.

Som et ledd i kartleggingen av trusselfaktorer vil det være nærliggende også å vurdere hvordan trusselfaktorene antas å påvirke $\varnothing$ kosystemene $\mathrm{i}$ fremtiden. På et generelt nivå har Klima- og miljødepartementet og Miljødirektoratet, i samarbeid med næringsmyndighetene, ansvar for å utarbeide prognoser for utviklingen i de relevante $\varnothing$ kosystemene. Slike prognoser utarbeides i lys av utviklingstrender, framtidige trusselfaktorer og forebyggende eller kompenserende tiltak for å ivareta $\varnothing$ kosystemene, for eksempel gjennom etablering av verneområder.

Metodikken som er utviklet for å identifisere, kategorisere og verdsette $\emptyset$ kosystemtjenester vil være nyttig for ivaretakelse av negative $\varnothing$ kosystemvirkninger i beslutningsprosesser. Gjennom analyser av fire tjenestekategorier; forsynende, regulerende, kulturelle og støttende tjenester, kan det foretas en vurdering av verdien til tjenestene som et velfungerende økosystem leverer. ${ }^{58}$ Målet er primært «å finne verdianslag for endringer i naturkapitalen og leveranse av økosystemtjenester på et nivå som ikke setter viktige $\varnothing$ kologiske prosesser i fare.» ${ }^{59}$ Verdien av høsting av viltlevende planter og dyr vil typisk være kvantifiserbare $\varnothing$ kosystemtjenester og dermed relativt enkle å inkludere. Men også mer indirekte tjenester kan ha stor verdi, slik som opprettholdelse av et stabilt klima, rensing av vann og luft, og opprettholdelse av kjemiske prosesser (næringsstoffkretsløp). Det vil normalt være store utfordringer ved verdsettelsen av støttende og regulerende tjenester, og dermed vanskelig å inkludere disse. Videre er det i noen tilfeller vanskelig å trekke et skille mellom hva som kvalifiserer som $\varnothing$ kosystemtjenester i seg selv og hva som er å anse som aktivitet som er avhengig av фkosystemtjenester. ${ }^{60}$ En økosystemtjenestetilnærming kan sikre nøyaktighet og pålitelighet i hvordan avveininger foretas. ${ }^{61}$

\footnotetext{
${ }^{54}$ Vannforskriften fn $29 \S 4$ som gjennomfører direktiv 2000/60/EF. En gjennomgang av vannforvaltningsplanene fra 2016 har vist at det var stor uenighet mellom myndighetene om virkningene av oppdrettsnæringens betydning for klassifiseringen av vannkvalitet, se O. K. Fauchald, «Hvilke krav stiller Grunnloven $§ 112$ til lakseoppdrettsnæringen? Forholdet mellom oppdrettsnæringen og villaks», FNI rapport 6/2016 s. 5-6.

${ }^{55}$ Forskrifter om opprettelse av verneområder, dispensasjonsadgangen etter nml $\S 48$ og plikten til å ta hensyn til virkninger av utenforliggende aktivitet på verneområder, $\mathrm{nml} \S 49$, setter rammene for hvordan oppdrettsvirksomhet kan påvirke verneområder. Det finnes eksempler på at verneområdeforskrifter har blitt endret for å legge til rette for oppdrettsvirksomhet, se https://www.miljovedtak.no/

${ }^{56}$ Se kvalitetsnormen (fn 29) art. 1 og 3.

${ }^{57}$ Se st.prp. nr. 79 (2001-2002) kapittel 4.3.2 og 4.4.2, innst. S. nr. 134 (2002-2003) og stortingsvedtak 294-299 for 2003, samt St.prp. nr. 32 (2006-2007) kapittel 6.1 og 6.3, innst. S. nr. 183 (2006-2007) og stortingsvedtak 425-429 for 2007. For en grundigere drøftelse av bakgrunnen for ordningen, se O. K. Fauchald, «Har $§ 112$ selvstendig betydning for vern av villaksen?», I O. K. Fauchald og E. Smith (red.) Mellom jus og politikk. Grunnloven § 112 , Fagbokforlaget, 2019, s. 230-231 og 234-235.

${ }^{58}$ NOU 2013:10 s. 128 og 132-135.

${ }^{59}$ Ibid. s. 214.

${ }^{60}$ Eksempelvis kan noen former for akvakultur anses som høsting fra $\emptyset$ kosystem og dermed som økosystemtjenester. Den typen industrialisert lakseoppdrett vi har i Norge kan imidlertid ikke anses som en slik høsting fra et økosystem, men må anses som en næring som er avhengig av og belaster eksisterende $\emptyset$ kosystemtjenester. Et motsatt standpunkt synes å bli lagt til grunn i ibid. s. 160 og 168, som bygger på G. I. van der Meeren, «Villaks og oppdrettslaks i et økosystemtjenesteperspektiv», Fisken og havet nr. 5 (2013) s. 15-16 og 35-36. For en grundig drøftels av tematikken, se J. Weitzman, «Applying the ecosystem services concept to aquaculture: A review of approaches, definitions, and uses», Ecosystem Services vol. 35 (2019) s. 194-206.

${ }^{61}$ NOU 2013:10 s. 212-224.
} 
Imidlertid har spørsmål om hvordan økosystemtjenester skal håndteres i samfunnsøkonomiske kost nytte analyser fått svært begrenset oppmerksomhet i norsk forvaltning. ${ }^{62}$ Videre er $\emptyset$ kosystemtjenestetilnærmingen grunnleggende antroposentrisk. Den kan dermed i begrenset grad bidra til å synliggjøre naturens egenverdi. ${ }^{63}$

Fra et saksbehandlerperspektiv er det utfordrende å forutsi konsekvensene av strategiske beslutninger fordi virkningene avhenger av mange faktorer, inklusive blant annet etterfølgende konkrete beslutninger, et potensielt bredt tilfang av andre påvirkningsfaktorer, økosystemenes langsiktige utviklingstrender og manglende eller mangelfull metode og veiledning. For strategiske beslutninger må kostnadene ved utredningene som utgangspunkt bæres av forvaltningen selv. Mens næringer som $\varnothing$ nsker endrede rammebetingelser kan forventes å presentere argumentasjon og fakta til støtte for endringene, må forvaltningen ta ansvar for å dokumentere negative økosystemkonsekvenser. En nærliggende strategi for forvaltningen kan være å peke på mulige utfordringer, men å overlate til tredjeparter, for eksempel forskere eller frivillige organisasjoner, å fremskaffe dokumentasjon gjennom høringer. ${ }^{64}$ For forvaltningen kan utredninger medføre forlengede beslutningsprosesser, kritikk for manglende handlekraft, synliggjøring av negative konsekvenser i strid med ønskede eller vedtatte politikkendringer, at $\emptyset$ nsket politikk ikke lar seg realisere og føre til politiske omkamper. Derfor vil forvaltningen ofte komme til at utredninger av $\varnothing$ kosystemvirkninger ved strategiske beslutninger medfører høye kostnader og begrenset nytte. Dette gjelder særlig der forvaltningen skal legge til rette for en viss type aktivitet, eksempelvis økt lakseoppdrett.

\subsection{Noen foreløpige konklusjoner}

Det er store utfordringer ved å identifisere de relevante $\varnothing$ kosystemer $\mathrm{i}$ beslutningsprosesser. Kunnskapsstatus og de verktøy myndighetene har for innsamling, analyse og formidling av data trekker i retning av at strategiske beslutninger baseres på virkninger for spesifikke arter og naturtyper snarere enn for $\varnothing$ kosystemene. Regelverket har fleksible kunnskapskrav om $\varnothing$ kosystemenes tilstand og påvirkningsfaktorer. Det er særlig to temaer som er viktige for fastleggingen av slike kunnskapskrav: Hvilken kunnskap som er tilgjengelig og om det er fastsatt miljøkvalitetsnormer. Ettersom negative $\emptyset$ kosystemeffekter av strategiske beslutninger er usikre i tid og rom, vil strenge kunnskapskrav generelt ha høye kostnader. Det er ikke etablert regelverk eller veiledningsmateriell for verdsetting av $\varnothing$ kosystemtjenester. Det er følgelig i stor grad overlatt til forvaltningen å ta stilling til hvordan man vil benytte informasjon om $\varnothing$ kosystemenes tilstand og utvikling i strategiske beslutningsprosesser. Dette innebærer at det lett kan oppstå uenighet om utredningskrav er oppfylt.

Et mål om at beslutninger skal være best mulig vitenskapelig forankret kan være en grunn til at utredninger i praksis begrenses til det biologiske mangfoldet som er kartlagt og til virkninger som kan forutsies med høy grad av sannsynlighet. Det å kreve utredning av miljøtilstander som ikke er kartlagt og virkninger som har høy grad av usikkerhet kan anses som uvitenskapelig og unødig kostbart. Imidlertid innebærer føre var prinsippet at det også i slike situasjoner skal «tas sikte på å unngå mulig vesentlig skade på naturmangfoldet» (nml § 9).

Utviklingen av overvåkningsverktøy og informasjonsteknologi gjør det mulig å stille klarere og strengere krav om utredning av økosystemvirkninger av strategiske beslutninger uten at dette trenger å bli urimelig byrdefullt, politisk uønsket eller uvitenskapelig. Selv om slike krav kan være samfunnsøkonomisk lønnsomme, kan de likevel bli ansett som lite kostnadseffektive og uønskede av

\footnotetext{
${ }^{62}$ Se instruks om utredning av statlige tiltak (FOR-2016-02-19-184) kapittel 2, Direktoratet for $\emptyset$ konomistyring, Veileder til utredningsinstruksen (2018) s. 22-40, Direktoratet for $\emptyset$ konomistyring, Veileder $i$ samfunnsфkonomiske analyser (2018) s. 171-174 og Klima- og miljødepartementet, Miljøutredninger etter utredningsinstruksen, 2001.

${ }^{63}$ Se NOU 2013:10 s. 212: Utredningen begrenses til «metoder for å synliggjøre betydningen $\emptyset$ kosystemtjenester har for menneskers velferd. Naturens egenverdi er ... både et selvstendig argument og et tilleggsargument for god og langsiktig forvaltning av naturressurser, men er ikke et tema i denne delen av utredningen [del III synliggjøring for bedre forvaltning].»

${ }^{64}$ Se eksempelvis O. K. Fauchald, «Juridisk betenkning angående foreslåtte endringer av motorferdselsloven for innføring av adgang til å etablere snøscooterløyper for fornøyelseskjøring», avgitt til Norsk Friluftsliv 29. januar 2015, https://www.jus.uio.no/ior/personer/vit/olefa/utredninger.html
} 
myndigheter og næringsaktører. ${ }^{65}$ Det er derfor nærliggende at prinsippet om $\varnothing$ kosystembasert forvaltning i praksis vil bli benyttet der det fra forvaltningens perspektiv vil medføre lave kostnader og betydelige goder. Gitt at prinsippet vil innebære $\varnothing \mathrm{kt}$ tidsbruk i planleggingsfasen og restriksjoner på hvordan aktiviteter kan utføres, må det forventes at kostnadene vil være spesielt høye der en virksomhet har høy økonomisk verdi. Godene som kan oppnås ved å anvende prinsippet kan estimeres ved å anslå verdien av de $\varnothing$ kosystemtjenestene som vil bli skadet som følge av beslutningen. Fordelingen av ansvar for fremskaffing av informasjon og utredning av konsekvenser mellom private aktører, forvaltningsorganer og politiske organer, samt det ansvar forvaltningsorganene har for å realisere politiske mål, tilsier at saksbehandlere i mange tilfeller vil legge større vekt på kostnadene ved strenge utredningskrav enn på godene som kan oppnås. Vi kan derfor forvente få utredninger av $\varnothing$ kosystemvirkninger ved strategiske beslutninger.

\section{Strategiske beslutninger om bærekraftig vekst i lakseoppdrett}

\subsection{Innledning}

I dette punktet skal vi drøfte hvordan prinsippet om økosystembasert forvaltning og føre var prinsippet ble brukt og kunne vært brukt ved tre strategiske beslutninger som er sentrale for målet om bærekraftig vekst i norsk lakseoppdrett: Inndeling i produksjonsområder (punkt 3.2), bruk av lakselus som miljøindikator (punkt 3.3) og fleksibilitet i lokalisering av produksjon (punkt 3.4). Innledningsvis skal det redegjøres for valget av de tre strategiske beslutningene og gis en kort oversikt over forvaltningsreformen.

Begrunnelsen for valget av de to første strategiske beslutningene er relativt åpenbar. Inndelingen i produksjonsområder og valg av miljøindikator for å bestemme produksjonsomfang innenfor produksjonsområdene sto helt sentralt i stortingsmeldingen som dannet utgangspunktet for reformen. ${ }^{66}$ Valget av den tredje beslutningen er mindre åpenbart, og skal diskuteres i det følgende. For å forstå hvorfor fleksibilitet i lokalisering av produksjon er av stor betydning for reformen, er det behov for først å gjøre rede for utgangspunktene for reformen.

I realiteten inneholder en akvakulturtillatelse to separate vedtak. Det ene omhandler produksjonsmengde (maksimalt tillatt biomasse, MTB) og fastsettes av Fiskeridirektoratet (statlig fagorgan). Det andre omhandler hvor produksjonen kan lokaliseres, noe som avgjøres av fylkeskommunen (regionalpolitisk organ) ${ }^{67}$ Det eksisterer et omfattende og komplekst regelverk som regulerer oppdrettsnæringens miljøvirkninger. ${ }^{68} \mathrm{I}$ tillegg må oppdrettsanlegg ha forurensningstillatelse (forurensningsloven, $1981 \mathrm{nr} .6, \S 11$ ). Samlet skal regelverket og tillatelsene resultere $\mathrm{i}$ at lakseoppdrett er miljømessig forsvarlig (akl $\S 6$ og 10). Hvorvidt kravet om miljømessig forsvarlighet er oppfylt, må avgjøres med utgangspunkt i hvor produksjonen rent faktisk finner sted. Kunnskap om hvilken fleksibilitet oppdretterne har til å flytte produksjon mellom lokaliteter er derfor helt sentralt for å kunne vurdere miljøkonsekvensene av reformen.

Da det nye forvaltningsregimet startet i 2017, fantes det 985 akvakulturtillatelser til lakseoppdrett fordelt på 913 lokaliteter. ${ }^{69}$ Tillatelsene omfattet en samlet produksjonsmengde (MTB) på i overkant av 0,8 millioner tonn, mens lokalitetene var klarert for en samlet produksjonsmengde på i overkant av 3,1 millioner tonn. Det var dermed gitt lokalitetsklarering for 3,9 ganger så mye biomasse som det var gitt produksjonstillatelser til. Lokalitetene var fordelt langs kysten - fra grensen mot Sverige i sør til grensen mot Russland i nord - med svært få lokaliteter (10) i området fra Sverige til Jæren (sydspissen av Norge),

\footnotetext{
${ }^{65}$ Se NOU 2012:16 Samfunnsфkonomiske analyser, s. 17.

${ }^{66}$ Meld. St. 16 (2014-2015) Forutsigbar og miljфmessig barekraftig vekst i norsk lakse- og фrretoppdrett.

${ }^{67}$ Fylkeskommunen kan også vedta at tillatelser skal kunne benyttes på andre lokaliteter og justere MTB og geografiske grenser for lokaliteter, se forskrift om tillatelse til akvakultur for laks, ørret og regnbueørret (FOR2004-12-22-1798) § 5 og kapittel 6.

${ }^{68}$ For oversikter, se Mikkelsen m.fl. fn 10 s. 5-34 og Fauchald, Grunnloven $§ 112$ og villaks fn 54 s. 4 og 7-8.

${ }^{69}$ Informasjonen fra Fiskeridirektoratet ved utgangen av 2017, innplasseringen i produksjonsområder (https://www.fiskeridir.no/Akvakultur/Tildeling-og-tillatelser/Kapasitetsjustering-

Trafikklyssystemet/Produksjonsomraader) og register over tillatelser og lokaliteter (https://register.fiskeridir.no/akvareg/). Antallet lokaliteter avviker noe fra de tall Fiskeridirektoratet oppga (960) i hovedsak fordi en del av lokalitetene ikke var i aktiv bruk.
} 
en hovedtyngde av lokaliteter (610) fra Jæren til Bodø, mindre tetthet av lokaliteter (217) fra Bodø til Finnmark, og relativt få lokaliteter (76) langs kysten av Finnmark. På kommunalt nivå var det stor variasjonen i antall lokaliteter. Frøya kommune hadde flest lokaliteter (34), ytterligere tre kommuner hadde 20 eller flere lokaliteter, ${ }^{70}$ og 18 kommuner hadde flere enn ti. ${ }^{71}$ I den andre enden av skalaen hadde halvparten av totalt 270 kystkommuner to eller færre lokaliteter. ${ }^{72}$

Denne oversikten viser at det for store deler av kysten er høy tetthet av lokaliteter. I disse områdene er det betydelig rom for flytting av produksjon mellom lokalitetene. For disse områdene vil spørsmålet om fleksibilitet til å flytte produksjon være svært aktuelt i et kort tidsperspektiv. For andre deler av kysten er det mye mindre tetthet av lokaliteter, og det vil være større mulighet for å etablere nye lokaliteter. Her vil det være større kostnader ved å bygge opp infrastruktur og flytting. For disse områdene vil spørsmålet om fleksibilitet ha mer langsiktig aktualitet og være avhengig av behovet for å flytte produksjon ut av områder med stor tetthet. Uansett tidsperspektivet vil imidlertid spørsmålet om fleksibilitet ha stor generell betydning for håndteringen av næringens miljøvirkninger.

Det nye forvaltningsregimet legger opp til økt produksjon gjennom beslutninger hvert annet år basert på modellering av hvordan forekomst av lakselus vil påvirke overlevelsesevnen til vill laksefisk. Produksjonen kan maksimalt $\varnothing$ ke seks prosent ved disse beslutningene. Den første produksjons $\varnothing$ kningen ble vedtatt i 2017-18, og var basert på fire grupper av vedtak:

1. Regjeringsvedtak i oktober 2017 om klassifisering av produksjonsområder i henhold til det såkalte «trafikklyssystemet». ${ }^{73}$ Åtte produksjonsområder (1 og 7-13) ble klassifisert som grønne, tre $(2,5$ og 6$)$ som gule og to (3 og 4) som røde.

2. Departementsvedtak av kapasitets $\varnothing$ kningsforskriften som innebar at grønne områder skulle få generell produksjonsøkning og at $\emptyset$ kning i tillegg til dette kunne godkjennes basert på individuelle vurderinger i alle områder. Det ble ikke fattet vedtak om kapasitetsreduksjon. ${ }^{74}$

3. Enkeltvedtak som endret eksisterende tillatelser avhengig av produksjonsområdenes klassifisering (kapasitetsøkningsforskriften $\S \S 4$ og 5) og uavhengig av klassifisering ( $\S 10$ og $11)^{75}$

4. Enkeltvedtak om produksjonsøkning basert på to auksjoner ved endring av eksisterende eller tildeling av nye tillatelser. ${ }^{76}$

Enkeltvedtakene i punkt 3 og 4 bygget på henholdsvis en «tilbud -aksept»-modell og en auksjonsmodell der myndighetenes mulighet til å stille vilkår eller avstå fra vedtak om endring av tillatelsene var sterkt begrenset. ${ }^{77}$ Vedtakene om produksjons $\varnothing$ kning ble gjort uten separate vedtak om lokalitetsklarering, og forutsatte at de kunne gjennomføres innenfor rammene av ledig MTB i lokalitetene. Nye tillatelser hadde forbehold om lokalitetsklarering.

\footnotetext{
${ }^{70}$ Nærøy - 24, Alta - 20 og Hitra - 20.

${ }^{71}$ Austvoll - 19, Finnøy - 18, Kvinnherad - 17, Bømlo - 16, Vikna - 15, Gulen - 14, Smøla - 14, Karlsøy - 13, Hadsel - 13, Skjervøy - 13, Askvoll - 12, Flora - 12, Harstad - 12, Rødøy - 12, Øksnes - 12, Flatanger - 11 , Lurøy - 11, Troms $\emptyset-11$.

${ }^{72}$ Det var 113 kommuner som ikke hadde lokaliteter, 27 som hadde én lokalitet og 19 som hadde to lokaliteter. Tall for kystkommuner er fra 2017, før sammenslåing av en del kystkommuner.

${ }^{73}$ Se pressemelding 30. oktober 2017, https://www.regjeringen.no/no/aktuelt/regjeringen-skrur-patrafikklyset/id2577032/. Klassifiseringen ble foretatt i henhold til produksjonsområdeforskriften (2017 nr. 61).

${ }^{74}$ Forskrift om kapasitets $\varnothing$ kning for tillatelser til akvakultur med matfisk i sjø av laks, ørret og regnbueørret i 2017-2018 (FOR-2017-12-20-2397) § 3 og kapittel 3.

${ }^{75}$ Se Kunngjøring, jf. § 5 - Tilbud om kapasitetsøkning på eksisterende tillatelser (2 pst.- $\left.\varnothing \mathrm{kning}\right)$, udatert, og Kunngjøring, jf. $§ 11$ - Tilbud om kapasitetsøkning uavhengig av miljøstatus i produksjonsområder (inntil 6 pst.$\emptyset$ kning), udatert.

${ }^{76}$ Se forskrift om tildeling av nye tillatelser til akvakultur med matfisk i sjø av laks, ørret og regnbueørret i 2018 (2018 nr. 731), forskrift om tildeling av nye tillatelser til akvakultur med matfisk i sjø av laks, ørret og regnbueørret i 2018 - auksjon av restkapasitet (2018 nr. 1323) og regelverk for gjennomføring av auksjon av nye tillatelser til akvakultur med matfisk av laks, ørret og regnbueørret, fastsatt av NFD 23. mai 2018.

${ }^{77}$ For en diskusjon av forholdet mellom disse vedtakene og reglene om miljømessig forsvarlighet og omgjøring i akl $\S 6$ og 9, se O. K. Fauchald, «Juridisk utredning angående produksjonsområdeforskriften og kvalitetsnormen for villaks, avgitt til Norske lakseelver 4. november 2017», s. 8-11, (https://www.jus.uio.no/ior/personer/vit/olefa/utredninger.html)
} 
Ved utgangen av 2018 var det fattet vedtak som indikerte en produksjonsøkning på i overkant av tre prosent. Myndighetene og næringen har lenge antydet et mål om en femdobling av produksjonen innen 2050 sammenliknet med $2010 .^{78}$ Med seks prosents produksjonsøkning vil produksjonsmengden firedobles innen 2056 (figur 2). Et mer realistisk anslag basert på 3,5 prosents $\varnothing$ kning innebærer en tredobling i 2064. Et mål om femdobling innen 2050 er følgelig urealistisk under dagens rammer for det nye forvaltningsregimet.

\section{Figur 2: Produksjonsutvikling for oppdrettslaks ved 6 og 3,5\% фkning hvert annet år}

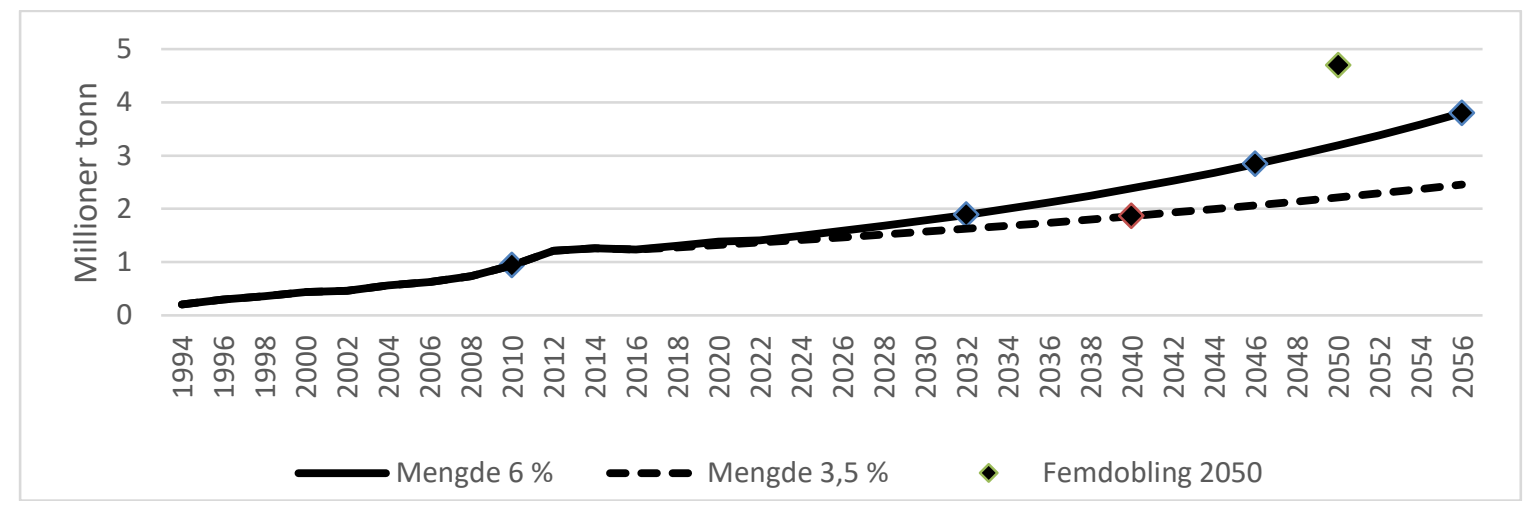

\subsection{Inndeling i produksjonsområder}

Til grunn for inndelingen av kysten i 13 produksjonsområder lå et ønske om å unngå smitte av lakselus og andre sykdommer mellom områdene, blant annet ved å etablere «branngater» med oppdrettsfrie soner. ${ }^{79}$ Grensene mellom produksjonsområdene i forskriften ble imidlertid basert på en avveining mellom hensyn til kontroll med spredning av lakselus, næringsinteresser og eksisterende forvaltningsstruktur. ${ }^{80}$ Forslaget om branngater ble ikke fulgt opp.

Figur 3 viser antallet aktive lokaliteter og samlet tillatt produksjon i henhold til tillatelser og lokalitetsklarering ved etableringen av produksjonsområdene. Det var stor variasjon i lokaliteter mellom områdene, fra ni i område 13 til 126 i område 3. Tilgangen til lokaliteter var særlig stor i områdene 3, 4, 6 og 9. Områdene 1, 2, 5, 11 og 13 skilte seg ut med klart lavest antall lokaliteter og godkjent produksjonsmengde. Det var relativt stor samvariasjon mellom antallet lokaliteter og mengde tillatt produksjon innenfor områdene, men med noen nyanser. Område 6 skilte seg ut med klart høyest produksjonsmengde for lokaliteter og også høyest produksjonsmengde for tillatelser, mens områdene 1 og 13 ligger i den andre enden av skalaen.

Figur 3: Antall lokaliteter og produksjonsmengde i produksjonsområdene i $2017^{81}$

\footnotetext{
${ }^{78}$ Se Meld. St. 16 (2014-2015) s. 15. En slik måloppnåelse forutsetter i overkant av åtte prosents produksjonsøkning hvert annet år fra og med 2020.

${ }^{79}$ Se Meld. St. 16 (2014-2015) kap. 9 og Effektiv og bærekraftig arealbruk fn 21 s. 139: «et sentralt tiltak for sykdomsbekjempelse» er at produksjonsområdene blir «adskilt med smitteforebyggende branngater» og at hvert produksjonsområde skulle «fungere som et overordnet smittehygienisk område.» Se også ot.prp. 61 (2004-2005) s. 50 .

${ }^{80}$ Se Nærings- og fiskeridepartementet, Høringsnotat - Implementering av Meld. St. 16 (2014-2015) vedlegg til høringsbrev datert 24. juni 2016 s. 6-24.

${ }^{81}$ Basert på statistikk fra Fiskeridirektoratet, se fn 8.
} 


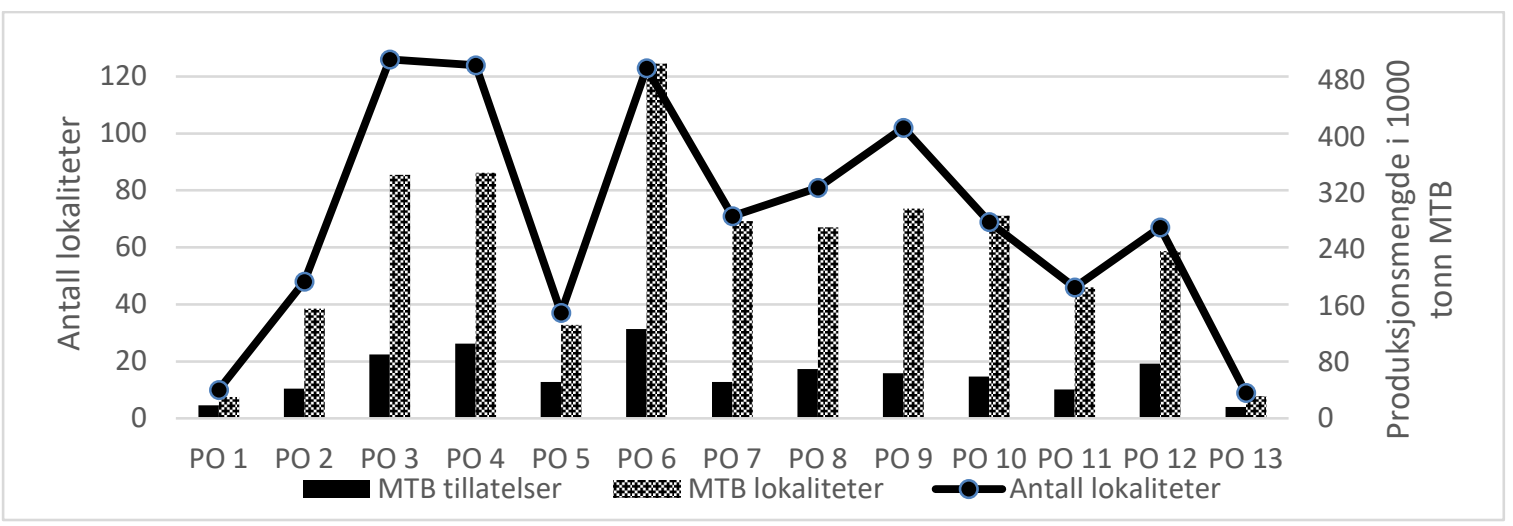

På landsbasis var lokalitetene i gjennomsnitt klarert for 3406 tonn MTB. Som vist i figur 4 var det også en stor variasjon mellom produksjonsområdene i gjennomsnitts-MTB på lokalitetene, fra et snitt på 2735 tonn i område 3 til 4170 tonn i område 6. Det var også svært stor variasjon mellom de største og minste lokalitetene innenfor alle områdene med unntak av område 13. Den minste lokaliteten var klarert for 325 tonn, mens den største for hele 8580 tonn.

Figur 4: Variasjon i MTB per lokalitet mellom og innenfor produksjonsområder i $2017^{\mathbf{8 2}}$

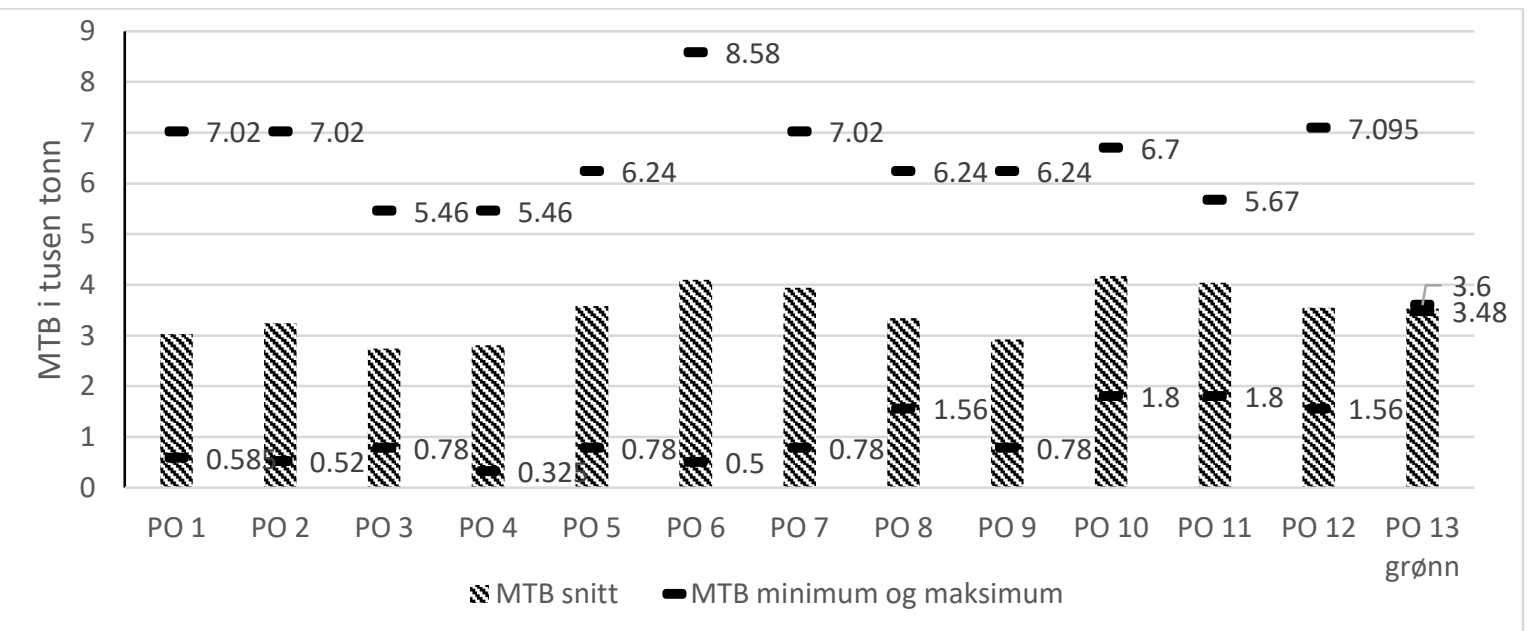

Innenfor hvert område innebærer de generelle reglene om produksjonsjustering at endringer blir like for alle aktører. Imidlertid åpnes det for betydelige forskjeller mellom aktørene innenfor produksjonsområdene gjennom enkeltvedtak (kapasitets $\emptyset$ kningsforskriften $\S \S 10 \mathrm{og} \mathrm{11}$ ), auksjoner, adgangen til lokalitetsklarering, samt i regler om drift av oppdrettsanlegg. ${ }^{83}$ Dermed kan miljøhensyn ivaretas innenfor hvert område til tross for at produksjonsjusteringen som utgangspunkt er gjort generell.

For å kunne ivareta miljøhensyn må oppdretterne ha mulighet til å stanse eller flytte produksjonen fra belastede lokaliteter. ${ }^{84}$ Evnen og viljen til å flytte er avhengig av tilgangen til ledig kapasitet på andre lokaliteter. Tilgangen til ledig kapasitet varierer betydelig mellom produksjonsområdene. I figur $5 \mathrm{er}$ områdene listet fra lav til høy fleksibilitet basert på tilgang til produksjonsvolum (MTB) ved oppstart av reformen i 2017 (heltrukken linje). Det var minst fleksibilitet i område 1 (forholdstall 1,64) og størst

\footnotetext{
82 Ibid.

${ }^{83}$ Slik variasjon følger av regelverket om nasjonale laksevassdrag og -fjorder, verneområdevedtak, vannforvaltningsplaner under vannforskriften og kommunale arealplaner.

${ }^{84}$ Her begrenses diskusjonen til to variabler som setter rammene for oppdretternes fleksibilitet til å flytte produksjon mellom lokaliteter - antallet lokaliteter en oppdretter har tilgang til og mengden ledig MTB i de aktuelle lokalitetene. For å måle fleksibiliteten brukes to forholdstall: 1) Forholdet mellom antall lokalitetsklareringer og produksjonstillatelser, og 2) Forholdet mellom MTB i lokalitetsklareringer og produksjonstillatelser. Høye forholdstall indikerer høy fleksibilitet.
} 
fleksibilitet i område 7 (forholdstall 5,44) ${ }^{85}$ Når det gjelder fleksibilitet på tillatelsesnivå (stolper) var det også betydelig variasjon. Fire produksjonsområder pekte seg ut med spesielt lav fleksibilitet $(1,5,6$ og 13). Figur 5 viser også effektene av produksjonsøkningen fra 2017 til 2018. De sterkeste utslagene ser vi i område 8, 9 og 11, der begge kategoriene av fleksibilitet ble betydelig redusert. De områdene som hadde lav fleksibilitet fra før fikk ikke redusert fleksibilitet. Generelt ble ikke fleksibiliteten endret i vesentlig grad, noe som reflekterer at produksjonsøkningen var lav.

Figur 5: Forholdstall for MTB og tillatelser ved utgangen av 2017 og $2018^{\mathbf{8 6}}$

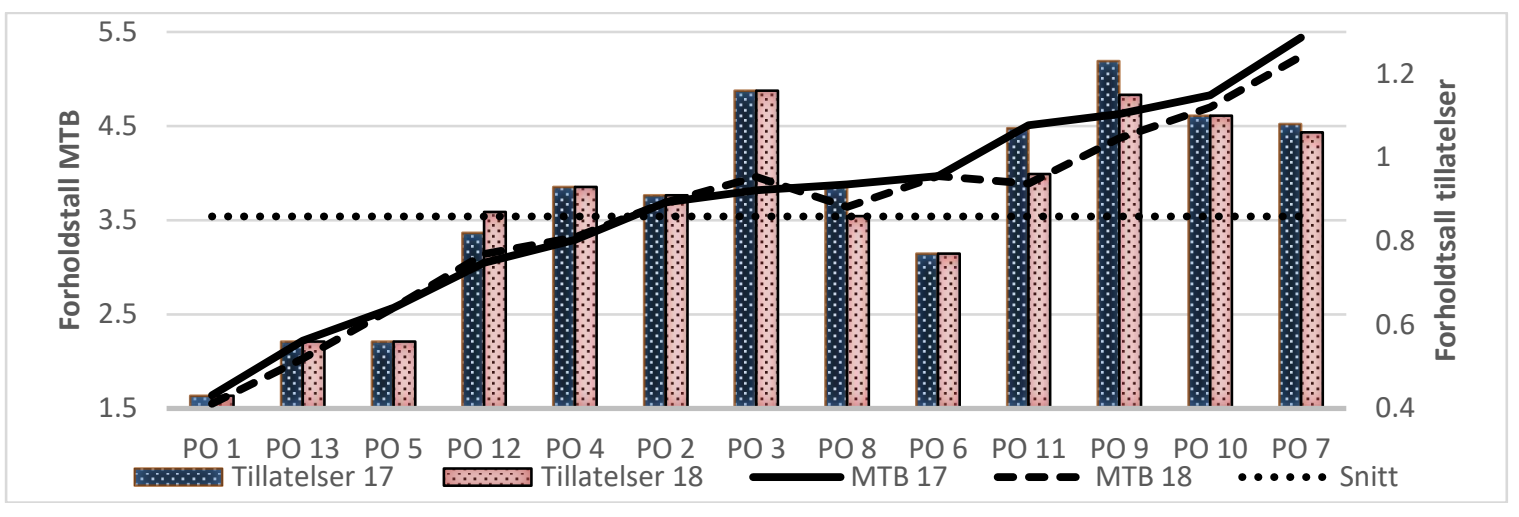

For produksjonsområdene med lav fleksibilitet kan det forventes et sterkt press for å få godkjent nye og større lokaliteter. Dette vil skape miljøproblemer ved de nye lokalitetene, men samtidig vil miljøproblemene ved eksisterende lokaliteter reduseres. Områdene 3, 7, 9 og 10 ligger godt an med stor fleksibilitet. For disse områdene har oppdretterne tilsynelatende gode muligheter for å strukturere produksjonen slik at miljøproblemer på belastede lokaliteter kan reduseres. I disse områdene vil det sannsynligvis være lavere press enn $\mathrm{i}$ andre områder for å få godkjent nye og for å få utvidet eksisterende lokaliteter.

Overfor fylkeskommunene og kommunene er det tatt i bruk et nytt insentiv for å legge til rette for nye og større lokaliteter ved at Havbruksfondet foretar utbetalinger basert på godkjente lokaliteter. Totalt ble det utbetalt over tre milliarder kroner i 2018 og 2019, i hovedsak som et resultat av den første produksjonsøkningen. ${ }^{87}$ Dette kommer i tillegg til skatteinntekter som følger av lakseoppdrett. ${ }^{88}$

Verken meldingen som innhentet Stortingets samtykke til reformen eller forarbeidene til produksjonsområdeforskriften inneholder utredninger av $\emptyset$ kosystemeffekter som kunne forventes av inndelingen i produksjonsområder $\left(\mathrm{nml} \S \S 7\right.$ og 10). ${ }^{89}$ Selv om initiativet til å inndele kysten i produksjonsområder var å legge til rette for en bedre produksjon ut fra hensyn til fiskehelse og miljø, viser prosessen fram mot vedtaket at andre hensyn ble dominerende. Hvorvidt og i hvilken grad inndelingen ville bidra til å oppfylle kravene om miljømessig forsvarlighet i akl §§ 6 og 10 og formålet om at næringen skal utvikles innenfor «rammene av en miljømessig bærekraftig utvikling» (produksjonsområdeforskriften $\S 1$ ) var derfor svært usikkert.

Når man skal vurdere $\varnothing$ kosystemeffektene av inndeling i produksjonsområder kombinert med den etterfølgende produksjons $\varnothing$ kningen, er utgangspunktet at det i noen områder vil bli et stort press for å få godkjent nye og større lokaliteter. Som redegjort for over, fattes vedtak om dette av fylkeskommunene

\footnotetext{
${ }^{85}$ Forholdstallene viser godkjent produksjonskapasitet for lokalitetene dividert med produksjonsmengde godkjent i tillatelser innen produksjonsområdet.

${ }^{86}$ Basert på statistikk fra Fiskeridirektoratet, se fn 8.

${ }^{87}$ Se Nærings- og fiskeridepartementet, Instruks for utbetalinger fra havbruksfondet, 5. januar 2017. Dette var en enorm økning fra utbetalingene i 2017 som var på 60 millioner kroner. Frøya kommune, med sine 34 lokaliteter, ble tildelt hele 116 millioner kroner. Disse utbetalingene tilsvarte omtrent kr. 23000 per innbygger. Blant fylkeskommunene var det Trøndelag som fikk høyest utbetaling med knappe 79 millioner kroner.

${ }^{88}$ Se NOU 2019:18 Skattlegging av havbruksvirksomhet. Fordelingen av skatteinntekter er i stor grad avhengig av hvor selskapene hører hjemme.

${ }^{89}$ Se Meld. St. 16 (2014-2015) s. 35, 46 og 57 og Høringsnotat fn 80. Stortingskomiteen har en relevant observasjon i Innst. $361 \mathrm{~S}$ (2014-2015) s. 9.
} 
etter prosesser som ikke er godt egnet til å ivareta miljøhensyn. På denne bakgrunn blir et helt sentralt spørsmål om og i hvilken grad det kan forventes at $\varnothing$ kosystembelastningen ved å ta i bruk nye lokaliteter eller $\varnothing$ ke produksjonen på lokaliteter som er i bruk, vil være større enn $\emptyset$ kosystemforbedringene som kan forventes der produksjonen stanses eller reduseres. Økosystemenes respons på menneskelig påvirkning, inklusive tålegrenser og evne til restitusjon, blir helt sentrale. Et grunnproblem er at man vet lite om slike tålegrenser. Men man vet at der det skjer grunnleggende endringer av $\emptyset$ kosystemene vil restitusjon ofte være ressurskrevende eller umulig. ${ }^{90}$ Dermed blir føre var prinsippet særlig aktuelt dersom det er fare for at økosystemenes tålegrenser overskrides. Det må også tas hensyn til at det er et behov for å opprettholde økosystemer som i størst mulig grad er upåvirket av menneskelige aktiviteter, både fordi det kan finnes arter og økosystemer der som er svært sensitive for påvirkning, og ut fra forsknings- og overvåkningsformål. I utgangspunktet kan dette ivaretas gjennom marine verneområder. Imidlertid har norsk praksis for oppretting av slike verneområder og håndtering av dem i relasjon til lakseoppdrett indikert at dette virkemidlet ikke er særlig effektivt. ${ }^{91}$

Forebygging av negative фkosystemeffekter kan også ivaretas gjennom stans av produksjon («brakklegging»). Det finnes regler om dette i akvakulturdriftsforskriften. Minimumskravet er brakklegging $\mathrm{i}$ to måneder etter hver produksjonssyklus, i praksis omtrent hvert annet år ( $\$ 40)$. Brakklegging skjer i hovedsak for å opprettholde god fiskehelse ( $\S 11 \mathrm{og} 40)$, men kan også pålegges som følge av at trendundersøkelser av bunnforholdene under anleggene viser «uakseptabel miljøtilstand» ( $\$ 36$ annet ledd). Dette praktiseres slik at pålegg om brakklegging for miljøformål bare blir aktuelt helt unntaksvis og stort sett på basis av undersøkelser av bunnforholdene rett under anlegget. ${ }^{92}$ Det er følgelig ikke etablert rutiner for brakklegging og flytting av produksjon med mål om å forebygge negative konsekvenser på et økosystemnivå.

En faktor som kan ha betydning for næringens evne og vilje til å ivareta økosystemeffekter er forekomsten av felleslokaliteter, det vil si lokaliteter med flere brukere. Ut fra generell kunnskap om miljøbelastning av fellesressurser, er det nærliggende å operere med en hypotese om at slike ressurser har dårligere miljøforhold enn ressurser med én bruker der det ikke foreligger tradisjoner eller regelverk for forvaltning av fellesressursen, noe som er situasjonen i oppdrettssektoren.$^{93}$ Det er derfor behov for å undersøke konsekvenser av felleslokaliteter, og om det er behov for å iverksette tiltak for å unngå negative effekter. Ved oppstarten av reformen hadde $18 \%$ av lokalitetene flere brukere, og innslaget av felleslokaliteter varierte mye mellom produksjonsområdene. ${ }^{94}$

Drøftelsen over viser at det er stor ulikhet i sårbarheten for negative $\varnothing$ kosystemeffekter blant produksjonsområdene. Områdene 3, 4 og 6 har flest lokaliteter og høyest godkjent og potensiell produksjonsmengde. Videre skiller produksjonsområdene 1, 5, 6 og 13 seg ut som områder som har lav fleksibilitet til å flytte produksjon internt i områdene. Endelig har områdene 2, 3 og 8 særlig høye antall felleslokaliteter med flere enn to brukere. Samlet tilsier drøftelsen over at det kan være særlig grunn til bekymring for økosystemeffekter av produksjonsområdeinndelingen i områdene 3 og 6 samt en viss grunn til bekymring for område 8 . For disse områdene ville det følgelig vært særlig viktig å foreta utredninger og vurdere kompenserende tiltak i tråd med prinsippet om økosystembasert forvaltning og føre var prinsippet.

\footnotetext{
${ }^{90}$ Se eksempelvis Westerlund fn 1 s. $12-16$.

${ }^{91}$ Se I. U. Jakobsen, «Integrated Ocean management in the Arctic: Comparative Analyses of the Implementation and Use of Marine Protected Areas in Canada and Norway», Ocean Yearbook vol. 32 (2018) s. 228-238 og L. H. Løchen, «Norges første marine nasjonalpark - gir den det ønskede vern?», Nordisk miljörättslig tidskrift, 2013:1 s. 71-86. Verneområdeforskrifter har blitt endret for å legge til rette for oppdrettsvirksomhet, lokaliteter for oppdrett har blitt godkjent i verneområder, og at det er blitt gitt dispensasjon fra verneområdeforskrifter for å lokalisere oppdrettsanlegg i eller rett i utkanten av verneområder. Foreløpig har det vært få slike saker og flere har vært kontroversielle. Ved utgangen av 2019 var det registrert syv relevante saker i Miljøvedtaksregisteret, se https://www.miljovedtak.no/

${ }^{92}$ Se Fiskeridirektoratet, Årsrapport 2018, s. 37-39. «Uakseptabel miljøtilstand» tolkes til å gjelde der tilstanden kategoriseres som kategori 4 - meget dårlig, noe som påvises i bare rundt $1 \%$ av undersøkelsene (i 2018 for 14 av 595 undersøkelser). Det rapporteres inn undersøkelser for bare ca. 2/3 av lokalitetene.

${ }^{93}$ Se eksempelvis E. Ostrom, Governing the Commons. The Evolution of Institutions for Collective Action, Cambridge University Press, 2015.

${ }^{94} \mathrm{Se}$ tabell 1 i vedlegget.
} 


\subsection{Lakselus som kriterium for produksjonsjustering}

Hovedregelen er at produksjonen skal justeres «i samsvar med områdets miljømessige bærekraft» (produksjonsområdeforskriften §8). Begrepet «miljømessig bærekraft» er nært beslektet med økosystembasert forvaltning og hovedregelen er tilsynelatende godt egnet til å oppfylle kravene om miljømessig forsvarlighet i akl $\S \S 6$ og 10 . Her skal vi drøfte om og i hvilken grad den andre strategiske beslutningen - lakselus som eneste indikator for beslutning om produksjonsjustering - kan oppfylle disse kravene.

Et sentralt mål for det nye forvaltningsregimet var styrket forutsigbarhet for lakseoppdrett. Ønsket om forutsigbarhet gjaldt særlig hvilke miljøtiltak som må gjennomføres for å oppnå produksjonsøkning. I lys av dette $\emptyset$ nsket forvaltningen å benytte indikatorer for å bestemme når målet om miljømessig bærekraft er oppfylt innenfor produksjonsområdene. Regjeringen uttalte at valget av miljøindikator skulle baseres på at indikatorene skulle være målbare og ha tilstrekkelig nær sammenheng med produksjonsvolumet $\mathrm{i}$ området. ${ }^{95}$ Basert på omfattende utredninger fra forskningsinstituttene, foreslo regjeringen i første omgang å benytte antall lakselus i oppdrettsanlegg som eneste indikator for vedtak om produksjonsjustering. ${ }^{96}$ Valget av miljøindikator var ikke basert på noen utredning i tråd med prinsippet om $\varnothing$ kosystembasert forvaltning eller føre var prinsippet ( $\mathrm{nml} \S \S 7,9 \mathrm{og} 10)$. Stortinget støttet regjeringens forslag, men fattet vedtak om at det skal utredes en framtidig modell der hver enkelt oppdretters tillatte miljøbelastning defineres, legges fram en handlingsplan mot resistens hos lakselus og utarbeides en strategi mot rømming som tar utgangspunkt $i$ en nullvisjon. ${ }^{97}$

Valget av lakselus som eneste indikator var følgelig kontroversielt og utgjorde et snevert valg av miljøindikator. Produksjonsområdeforskriften kompenserte for dette ved regler om at lakselus skal brukes til å «overvåke» miljøpåvirkningen og at departementet skal fatte sitt vedtak basert på en vurdering av om «miljøpåvirkningen i et produksjonsområde er akseptabel, moderat eller uakseptabel» (§ 8). I forarbeidene understrekes det også at det er «totalvurderingen til departementet som avgjør om det lyses ut tilbud om vekst eller ikke.» ${ }^{98}$ Slike bredere miljøvurderinger ville kunne omfatte $\emptyset$ kosystemeffekter. På dette punktet er imidlertid forskriftens forarbeider tvetydige, ettersom de også indikerer et automatisert system basert på miljøindikatoren ut fra hensyn til forutsigbarhet. ${ }^{99}$

Den 30. oktober 2017 annonserte Nærings- og fiskeridepartementet: «Regjeringen skrur på trafikklyset». Anledningen var den første klassifiseringen av miljøpåvirkningen i produksjonsområdene. På tre vesentlige punkter handlet departementet i strid med prinsippet om økosystembasert forvaltning. For det første ble det ikke, i alle fall ikke offisielt, foretatt noen overordnet vurdering av om miljøpåvirkningen $\mathrm{i}$ et produksjonsområde var akseptabel. Beslutningen om miljøpåvirkningen ble offisielt bare fattet på basis av forekomsten av lakselus. Det samme mønsteret gjentok seg ved klassifiseringen i $2020 .{ }^{100}$

For det andre har lakselus negative effekter for all vill laksefisk, inklusive villaks, sjøørret og sjørøye. Dette ble lagt til grunn i forskriften $\S 8$ ved at man brukte begrepet «vill laksefisk», og ikke «villaks». Indikatoren som skulle brukes var ifølge forarbeidene sannsynligheten for at en viss andel av disse

\footnotetext{
${ }^{95}$ Meld. St. 16 (2014-2015) s. 54-55.

${ }^{96}$ Se ibid. s. 56 og Høringsnotat fn 80. Se også Politisk plattform for en regjering utgått av Høyre og

Fremskrittspartiet («Solberg 1-regjeringen»), Sundvollen, 16. oktober 2013, s. 31-32.

${ }^{97}$ Innst. 361 S (2014-2015) s. 8 og 12 og Stortingets vedtak nr. 678-681, 15. juni 2015. Flertallet i

stortingskomiteen mente at det også måtte utredes indikatorer for svinn og sykdom, men dette kom ikke med i stortingsvedtakene. Vedtakene er fulgt opp gjennom Nærings- og fiskeridepartementet, Handlingsplan mot resistens mot legemidler mot lakselus, 2017, og Nærings- og fiskeridepartementet, Strategi mot rømming fra akvakultur, 2017.

${ }^{98}$ Høringsnotat fn 80 s. 34.

${ }^{99}$ Ibid. s. 4 og 29-30.

${ }^{100}$ Se Høring - Utkast til forskrift om kapasitetsøkning for tillatelser til akvakultur med matfisk i sjø av laks, ørret og regnbueørret i 2017/2018, Høringsnotat, 6. november 2017, punkt 2.1.1 og 2.1.2. Det finnes ikke tilsvarende dokumentasjon av departementets vurderinger for beslutningen i 2020, men departementet uttalte at «[f]argen settes ut fra hvordan lakselusa påvirker villaksen i området», se pressemelding 4. februar 2020, Regjeringen skrur på trafikklyset i havbruksnæringen.
} 
villfiskpopulasjonene ville dø som følge av lakselus. ${ }^{101}$ Som ledd i klassifiseringen ble det oppnevnt eksperter for vurdering av lusepåvirkning. Departementet ga ekspertgruppen i mandat «å gi en beskrivelse av lakselusindusert villfiskdødelighet per produksjonsområde» og presiserte at i 2017 skulle «hovedvekten ... legges på villaks.» ${ }^{102}$ I henhold til mandatet tok klassifiseringen av områdene utgangspunkt i dødeligheten for utvandrende smolt av villaks og brukte ikke tilsvarende vurderinger for sjøørret og sjørøye. ${ }^{103}$ Tilsvarende ble det heller ikke i 2020 tatt hensyn til sjøørret og sjørøye ved klassifiseringen av produksjonsområdene. ${ }^{104}$ Den mangelfulle vurderingen av sjøørret og sjørøye innebærer at klassifiseringen av områdene ikke oppfylte minstekravet om bruk av «vill laksefisk» som miljøindikator. En rapport viser at statusen for nesten halvparten av sjøørretbestandene er dårlig eller svært dårlig og lakselus er den klart viktigste påvirkningsfaktoren. ${ }^{105}$

For det tredje kom departementet til at det var forsvarlig å fravike ekspertgruppens konklusjoner til fordel for oppdrettsnæringen ved at ett område fikk bedre klassifisering enn anbefalt. Departementet fremførte usikkerhet i ekspertvurderingene og «at de positive samfunns $\varnothing$ konomiske konsekvensene er vurdert til å være betydelig større enn de negative» som begrunnelse. ${ }^{106}$ Dermed ble produksjonsområde 7 klassifisert som grønt i stedet for gult. Dette gjentok seg ved klassifiseringen av produksjonsområder i 2020. Denne gangen ble imidlertid hele tre produksjonsområder gitt bedre klassifisering enn det de vitenskapelige rådene skulle tilsi - to som grønt i stedet for gult, og ett som gult i stedet for rødt. ${ }^{107}$

Til tross for at produksjonsområdeforskriften $\S 8$ og Stortingets vedtak legger til rette for økosystembasert forvaltning, var beslutningene om klassifisering av produksjonsområdene i 2017 og 2020 i strid med prinsippet om økosystembasert forvaltning og føre var prinsippet. Det ble heller ikke fremsatt noen begrunnelse for beslutningene, i strid med $\mathrm{nml} \S 7$. Et hovedargument for fremgangsmåten kan være at miljøpåvirkninger kan ivaretas ved andre virkemidler, men noen slik argumentasjon er ikke fremført av departementet. Analysen over indikerer at det ikke ville vært særlig byrdefullt for departementet å etterleve prinsippet om фkosystembasert forvaltning ved klassifiseringene av produksjonsområdene. Hovedgrunnene til at dette ikke ble gjort synes å være hensynet til forutsigbar vekst i lakseoppdrett. Departementets saksbehandling bekrefter forventningen i punkt 2.6 om en sterk motstand mot utredning av økosystemeffekter ved strategiske beslutninger innen lakseoppdrett.

\subsection{Fleksibilitet mellom produksjonsområder}

Den tredje strategiske beslutningen - fleksibilitet til å flytte produksjon mellom produksjonsområder har blitt truffet mer i det skjulte. ${ }^{108}$ Fra 2010 fikk lakseoppdrettere fleksibilitet til å flytte produksjon mellom regioner gjennom vedtak om «interregionalt biomassetak». ${ }^{109}$ Det var ikke åpenbart at denne

\footnotetext{
${ }^{101}$ Meld. St. 16 (2014-2015) s. 60-61. Det ble spesifisert tre alvorlighetsgrader: lav ved mindre enn 10 prosent dødelighet, middels ved mellom 10 og 30 prosent dødelighet og stor ved over 30 prosent dødelighet.

${ }^{102}$ Sitert fra Rapport fra ekspertgruppe for vurdering av lusepåvirkning. Vurdering av lakselusindusert villfiskdфdelighet per produksjonsområde, s. 3.

${ }^{103}$ Ibid. s. 18 og råd fra Styringsgruppen for vurdering av lusepåvirkning, datert 15. september 2017, s. 2-4.

${ }^{104}$ Se Råd fra Styringsgruppen for vurdering av lusepåvirkning 2018-2019 (17. november 2019) s. 9.

105 Vitenskapelig råd for lakseforvaltning, «Klassifisering av tilstanden til 430 sjøørretbestander», Temarapport nr. 7, 2019 s. 5-7, 17 og 28-30.

${ }^{106}$ Høring - Utkast til forskrift om kapasitetsøkning for tillatelser til akvakultur med matfisk i sjø av laks, ørret og regnbueørret i 2017/2018 punkt 2.1.2. Her la departementet tilsynelatende avgjørende vekt på et hensyn som etter forskriftens $\S 8$ må anses som utenforliggende. Dette vil normalt medføre at vedtaket er ugyldig på dette punktet.

${ }^{107}$ Dette gjaldt produksjonsområde 2 (klassifisert som grønt mens rådet tilsa gult), 3 (klassifisert som gult mens rådet tilsa rødt) og 7 (klassifisert som grønt mens rådet tilsa gult). Se Råd fra Styringsgruppen for vurdering av lusepåvirkning 2018-2019 (17. november 2019) s. 7 og pressemelding 4. februar 2020, Regjeringen skrur på trafikklyset i havbruksnæringen. I sistnevnte uttales: «Nærings- og fiskeridepartementet baserer fargeleggingen på naturfaglige råd. I områder der påvirkningen av lakselus har vært ulik i 2018 og 2019 har departementet gjort en samlet vurdering hvor også samfunnsøkonomiske konsekvenser har spilt inn. Dette er i tråd med Havbruksmeldingen.»

${ }^{108}$ Regjeringen holdt spørsmålet åpent da saken ble lagt fram for Stortinget, men antydet at adgang til fleksibilitet eventuelt ville bli begrenset til «miljøbegrunnet flytting», se Meld. St. 16 (2014-2015) s. 68-69.

${ }^{109}$ Fra 2004 til 2010 var det anledning til å flytte produksjon innenfor Fiskeridirektoratets syv regioner, ibid.
} 
fleksibiliteten skulle videreføres. Et hovedpoeng ved opprettelse av produksjonsområder var miljømessig bærekraftig produksjon innenfor separate geografiske områder.

I forarbeidene til reformen vurderte departementet ulike alternativer for fleksibilitet mellom produksjonsområdene. Til tross for en ekspertutredning som uttalte at «bærekraft og effektiv arealutnyttelse må komme foran distriktspolitiske hensyn» og at miljømyndighetene var negative selv til «miljøbegrunnet flytting», ${ }^{110}$ konkluderte departementet med at de «miljømessige konsekvensene ved de ulike alternativene er vanskelig å forutberegne». ${ }^{111}$ Resultatet ble $\varnothing \mathrm{kt}$ fleksibilitet til å flytte produksjon mellom områdene. Ved innplasseringen av eksisterende lokaliteter i produksjonsområdene, uttalte departementet som mål å «sikre at alle selskaper kan få drive i minst to produksjonsområder». ${ }^{112}$ Oppdretterne fikk følgelig fleksibilitet til å velge områdetilhørighet for sine tillatelser. Departementet uttalte også at oppdretterne «kan få felles biomassetak mellom disse produksjonsområdene», ${ }^{113}$ noe som ble kombinert med at departementet opphevet vilkåret om lokal videreforedling av produksjonen ved felles biomassetak mellom to produksjonsområder (akvakulturdriftsforskriften $§ 48 \mathrm{a}$ ). Endelig ble det innført ytterligere fleksibilitet ved at oppdrettere innen samme konsern kan innvilges felles biomassetak for tre områder som grenser til hverandre (akvakulturdriftsforskriften $\S 48 b$ ).

Gitt usikkerheten ved miljøvirkningene av denne fleksibiliteten, kunne det forventes at det ble utarbeidet mer detaljerte regler som skulle hindre miljøskadelig flytting. Et nærliggende eksempel er at en oppdretter flytter produksjonen inn i et område som forventes å komme dårlig ut i klassifiseringen i håp om at området produksjonen flyttes ut av vil komme bedre ut. Oppdretteren kan på denne måten sikre seg maksimal produksjons $\varnothing$ kning, men konsekvensen kan bli varige negative $\varnothing$ kosystemeffekter. Fiskeridirektoratet «kan fatte vedtak om begrensninger i utnyttelse av felles biomassetak ... dersom selskapet ikke kan dokumentere tilstrekkelig kontroll med miljøpåvirkning som omfattes av reguleringer for produksjonsområdene», (akvakulturdriftforskriften $\S 48 \mathrm{~b}$ femte ledd). Utover dette inneholder verken regelverket eller vedtakene om felles biomassetak virkemidler som skal hindre uønskede $\emptyset$ kosystemeffekter.

Grensene for hvor mye en oppdretter i praksis kan produsere i et produksjonsområde er følgelig ikke begrenset til den mengden som kan produseres i henhold til oppdretterens tillatelser i området, slik man lett kan få inntrykk av ut fra regelverket, saksbehandlingen og akvakulturtillatelsene. Det er to helt andre faktorer som bestemmer hvor mye produksjon en oppdretter kan ha $\mathrm{i}$ et produksjonsområde: 1) Oppdretterens samlede produksjonsmengde i tillatelsene i områdene som er omfattet av vedtak om felles biomassetak og 2) Oppdretterens tilgang til MTB i lokaliteter i produksjonsområdene. Dermed blir vedtakene om felles biomassetak sentrale for å kunne vurdere $\varnothing$ kosystemeffekter av produksjons $\varnothing$ kninger.

Fiskeridirektoratet offentliggjør ikke informasjon om vedtak om felles biomassetak. På forespørsel svarte direktoratet at de ikke hadde slik informasjon tilgjengelig og avslo å fremskaffe informasjonen. ${ }^{114}$ Analysen nedenfor er derfor basert på 25 vedtak om felles biomassetak som ble funnet ved søk i

\footnotetext{
${ }^{110}$ Ibid.

${ }^{111}$ Høringsnotat fn 80 s. 41, med følgende begrunnelsen: «Et alternativ med mindre fleksibilitet vil gi betydelige incentiver til å løse miljøutfordringer innenfor det enkelte produksjonsområde. Samtidig vil større fleksibilitet kunne bidra til å raskere redusere miljøpåvirkningen ved at biomasse kan flyttes ut av særlig belastete områder. Dette vil imidlertid ikke løse de underliggende miljømessige utfordringene, og kan bidra til å redusere de miljømessige incentivene som ligger i det nye systemet. Samtidig gir større geografisk fleksibilitet næringen mulighet til i større grad å velge bort de mindre gunstige lokalitetene med hensyn til lakselus, noe som på sikt er positivt.»

${ }^{112}$ Innplassering i henhold til produksjonsområdeforskriften $\S \S 5$ og 7, se brev fra Nærings- og fiskeridepartementet, Vedrørende implementering av nytt system for kapasitetsjusteringer i norsk lakse- og ørretoppdrett, datert 20. september 2017, s. 3 og NFD pressemelding 7. juli 2017,

https://www.regjeringen.no/no/aktuelt/regler-for-nytt-oppdrettssystem-er-klare/id2564368/ Se også Nærings- og fiskeridepartementet, Høring - diverse forslag til endringer i forbindelse med implementering av nytt system for kapasitetsjusteringer i havbruksnæringen, brev av 19. mai 2017.

113 Ibid.

${ }^{114}$ Brev til forfatteren fra Fiskeridirektoratet, Svar på forespørsel om vedtak om felles biomassetak i produksjonsområder, 2. februar 2019. Dokumenter fra saken kan finnes på https://www.jus.uio.no/ior/personer/vit/olefa/saker.html. Vedtakene fattes av Fiskeridirektoratets regionskontorer.
} 
direktoratets journaler. ${ }^{115}$ Disse vedtakene omfattet omtrent 60 prosent av total MTB ved utgangen av 2018. Litt under halvparten av dette kunne flyttes mellom to områder og litt over halvparten kunne flyttes mellom tre og fire områder. Det var stor variasjon mellom områdene i antall tillatelser og produksjonsmengde som er omfattet av vedtakene (se tabell $2 \mathrm{i}$ vedlegg).

Allerede ved den første produksjonsjusteringen var det derfor veldig uklart hvor eksisterende og økt produksjon kom til å bli lokalisert. Ettersom flytting ut av et produksjonsområde vil kompenseres av flytting inn i et annet område, kan det ved første øyekast se ut til at flytting mellom områdene vil være et «nullsumspill» der samlede miljøeffekter vil være nøytrale. Dette utgangspunktet må imidlertid modifiseres. I noen situasjoner vil det være lettere å flytte ut av enn inn i et gitt produksjonsområde, blant annet på grunn av variasjonen i antall lokaliteter og produksjonsmengde i områdene samt oppdretternes tilgang til tillatelser og lokaliteter. Videre må det tas hensyn til områdenes miljøklassifisering. Med enkelte unntak hadde oppdrettere god tilgang til lokaliteter i aktuelle produksjonsområder. ${ }^{116}$ De aller fleste vedtakene gjorde det mulig for oppdretterne - $\mathrm{i}$ alle fall $\mathrm{i}$ teorien - å flytte all sin produksjon inn i ett av områdene. Generelt er det produsenter med stort produksjonsvolum som har fått vedtak om felles biomassetak for tre eller fire produksjonsområder. Selv om det er en viss begrensning i tilgangen til lokaliteter i enkelte av produksjonsområdene under disse tillatelsene, gir de tilgang til flere områder og dermed betydelig fleksibilitet.

Tabell $2 \mathrm{i}$ vedlegget analyserer mulige miljøkonsekvenser av fleksibiliteten til å flytte produksjon, og funnene der indikerer at det kun er to produksjonsområder der det forventes miljømessig positivt resultat. Dette er områder som har svært liten produksjon og fleksibilitet til å flytte produksjon internt i områdene, og som så langt har hatt liten miljøbelastning. De områdene som ser ut til å få de mest negative miljøkonsekvensene er områder som hadde dårligst klassifisering i 2017 (to røde og ett gult område). En grunn er at det var få vedtak som åpnet for å flytte en liten andel av produksjonen ut av røde områder ( 3 og 4) og inn i gule $\left(2,5\right.$ og 6) eller grønne områder. ${ }^{117}$ Muligheten for å flytte produksjon til de nærmeste grønne områdene (1 og 7) var svært begrenset på grunn av lavt antall tilgjengelige lokaliteter. Dette medførte at område 2 ble særlig utsatt for press om $\varnothing \mathrm{kt}$ produksjon for å avlaste de røde områdene.

Beslutningen om oppdretteres fleksibilitet til å flytte produksjon mellom produksjonsområder og vedtakene om felles biomassetak gjør det vanskelig å forutsi størrelsen av produksjon i områdene. Til tross for at det kan være rasjonelt for enkelte oppdrettere å prioritere $\varnothing$ kosystemeffekter, ${ }^{118}$ kan det generelt forventes strategisk tilpasning for å sikre størst mulig økonomisk overskudd. Om oppdrettere vil prioritere kortsiktig eller langsiktig overskudd vil være kontekstavhengig. Strategisk tilpasning kan for eksempel skje ved å flytte produksjon for å komme best mulig ut av produksjonsjusteringer, restrukturering av eierskap for å få tilgang til økt fleksibilitet og søknader om nye og større lokaliteter. Det er eksempelvis sannsynlig at det vil bli et sterkt press for å få tilgang til lokaliteter i område 1 og 7 .

Vedtakene om felles biomassetak innebærer at det kan bli økt produksjon i områder der det er størst fare for at $\emptyset$ kosystemenes tålegrense vil bli overskredet (røde områder). Vedtakene ser ikke ut til å redusere faren for slike virkninger i andre områder. Fleksibiliteten mellom produksjonsområdene medfører også $\emptyset \mathrm{kt}$ usikkerhet om hvilke virkninger lakseoppdrett vil få for $\emptyset$ kosystemene, og dermed $\varnothing \mathrm{kt}$ behov for anvendelse av føre var prinsippet.

\footnotetext{
${ }^{115}$ Dette er vedtak som var fattet innen utgangen av 2018, de fordeler seg som følger: 18 vedtak om felles biomassetak for to produksjonsområder, 5 om tre områder og 2 om fire områder. Vedtakenes innhold varierer betydelig. Der vedtakene verken spesifiserer hvilke tillatelser eller hvor mye MTB som omfattes innen områdene eller samlet MTB, tolkes del å gjelde alle relevante tillatelser som oppdretteren innehar.

${ }^{116}$ De viktigste unntakene var Lerøy Midt AS som ikke kunne flytte produksjon fra område 6 til 5 og NRS Finnmark som ikke kunne flytte produksjon fra område 12 til 11.

${ }^{117} \mathrm{Av}$ de 25 vedtakene er det er bare tre som åpner for å flytte til sammen 46878 tonn (rundt $25 \%$ av samlet MTB) ut av de to røde produksjonsområdene (3 og 4) til gule og grønne områder, og tre vedtak som åpner for å flytte til sammen 26912 tonn (rundt $12 \%$ av samlet MTB) fra gule (2, 5 og 6) til grønne områder. Den samlede flyttingen av produksjon mellom områdene 4, 5 og 6 er i praksis avhengig av hvordan én aktør velger å fordele sin produksjon, se Fiskeridirektoratets vedtak: Marine Harvest Norway AS, Felles biomassetak mellom produksjonsområder for selskap som videreforedler en høy andel fisk - Produksjonsområdene 4, 5 og 6, 18. oktober 2017.

${ }^{118}$ Vormedal fn 9 s. 53-55.
} 


\section{Miljørettsprinsippene - nyttige verktøy eller utopiske mål?}

Drøftelsen over viser at de viktigste strategiske beslutningene ved innføringen av «trafikklys» for lakseoppdrett i Norge ble tatt uten at prinsippet om økosystembasert forvaltning og føre var prinsippet ble ivaretatt. Det samme gjelder etterfølgende vedtak for å gjennomføre beslutningene. Dette har skjedd til tross for at forvaltningen hadde en plikt til å benytte prinsippene etter nml §§ 7-10 og var forpliktet til å sikre at lakseoppdrett «etableres, drives og avvikles på en miljømessig forsvarlig måte» (akl § 10). Videre skjedde det til tross for at reformen har som mål å fremme næringens «lønnsomhet og konkurransekraft innenfor rammene av en miljømessig bærekraftig utvikling» (produksjonsområdeforskriften $\S 1$ ).

En hovedgrunn til at prinsippene og målet ikke ble fulgt opp synes å være at fiskerimyndighetene har prioritert forutsigbar vekst for næringen framfor $\varnothing$ kosystembasert forvaltning og reduksjon av usikkerhet knyttet til negative miljøvirkninger. Reformen avspeiler en tilnærming til naturressursforvaltning der næringsaktører gis et betydelig ansvar for å oppfylle generelle miljøforventninger, og der gjennomføring og kontroll i stor grad skjer i en prosess mellom myndighetsorganer og næringsaktører som var lite formalisert og åpen.

Prinsippet om $\varnothing$ kosystembasert forvaltning utfordrer næringsliv, forvaltningsorganer og forskningsmiljøer på et grunnleggende nivå. Dette gjelder særlig der prinsippet anvendes på strategiske beslutninger, og et sentralt spørsmål er om og i hvilken grad prinsippet er egnet for anvendelse på slike beslutninger. Som et generelt utgangspunkt er det vanskelig å argumentere mot at strategiske beslutninger må fattes på et godt kunnskapsgrunnlag og at et slikt kunnskapsgrunnlag må vurdere viktige konsekvenser for $\varnothing$ kosystemer. Men, som vist over, har ivaretagelse av $\emptyset$ kosystemeffekter ulike kostnader for ulike aktører, og dette medfører betydelig motstand mot anvendelse av prinsippet i praksis. Drøftelsen indikerer at både næringsliv og offentlige myndigheter ofte vil kunne anse prinsippet om $\varnothing$ kosystembasert forvaltning som for kostnadskrevende.

Dersom slike kostnader innebærer mangelfull utredning av økosystemeffekter, vil det oppstå situasjoner der usikkerhet aktualiserer føre var prinsippet. Dersom dette prinsippet var blitt brukt i praksis, ville det oppstå en synergi mellom prinsippene; faren for ikke å oppnå goder ved manglende utredning av фkosystemeffekter som følge av anvendelse av føre var prinsippet vil gi et insentiv til å utrede slike effekter. Slik sett kan en effektiv gjennomføring av føre var prinsippet være en sentral forutsetning for at også prinsippet om økosystembasert forvaltning skal kunne fungere. Studien over viser imidlertid at både næringsaktører og myndigheter har unnlatt å anvende føre var prinsippet.

For strategiske beslutninger ser det følgelig ut til at en effektiv anvendelse av prinsippene møter grunnleggende utfordringer. Dermed oppstår spørsmålet om uakseptable negative $\varnothing$ kosystemeffekter best kan håndteres gjennom andre virkemidler. En nærliggende mulighet er bruk av miljøkvalitetsnormer og rettighetsbestemmelser. For marine kystområder er slike virkemidler svakt utviklet $\mathrm{i}$ det norske rettssystemet. ${ }^{119}$ På to punkter innebærer imidlertid EØS-avtalen at det kan forventes en $\varnothing \mathrm{kt}$ bruk av slike virkemidler i Norge. Vanndirektivet innebærer strengere krav til lakseoppdrett i kystnære områder, og konsekvensutredningsdirektivene innebærer krav til utredning av miljøkonsekvenser av lakseoppdrett. En slik utvikling vil bidra til mer effektiv gjennomføring av prinsippene i relasjon til både konkrete og strategiske beslutningsprosesser.

Reformen inviterer til noen avsluttende tanker om rollen til forskningsmiljøer og fagmyndigheter, samt om fragmentering av normer og beslutningsprosesser. Et interessant perspektiv ved reformen er den sentrale rollen til naturvitenskapelige forskningsmiljøer og fagmyndigheter under forberedelse og gjennomføring. Analysen indikerer at disse har møtt utfordringer med prinsippene i praksis. Det ser ut til at det har vært to viktige årsaker til dette; begrensninger i det mandatet som blir gitt av politiske myndigheter (departementet) og disse myndighetenes tolkning og bruk av de råd som blir gitt. Den høye graden av usikkerhet som ligger innebygget $\mathrm{i}$ å anvende prinsippet om $\varnothing$ kosystembasert forvaltning på strategiske beslutninger ser ut til å komme i et spenningsforhold til forskeres og fagmyndigheters forventninger til den etterfølgende beslutningsprosessen. Videre innebærer politiske myndigheters motstand mot å anvende føre var prinsippet en utfordring for hvordan forskere og fagmyndigheter skal forholde seg til prinsippet.

\footnotetext{
${ }^{119}$ Se O. K. Fauchald, «Har $§ 112$ selvstendig betydning for vern av villaksen?» I Fauchald og Smith (red.) Mellom jus og politikk: Grunnloven \$ 112, 2019 s. 231-252.
} 
I denne studien har vi sett fragmentering av normer og beslutningsprosesser langs to dimensjoner. Den første er den institusjonelle fragmenteringen mellom næringsmyndigheter, miljømyndigheter og regionale/lokale myndigheter. Den andre er fragmentering mellom normer som har ulik status. I denne studien ser vi at dette har resultert i en betydelig kompleksitet i forholdet mellom lovgivning, EØSregler, veiledende normer og enkeltvedtak innenfor akvakultursektoren. Studien viser at den store kompleksiteten kan medføre selektiv påberopelse av normer og strategisk tilnærming til beslutningsprosesser ut fra ønsket om å prioritere noen interesser foran andre. Et eksempel er den strategiske beslutningen om fleksibilitet mellom produksjonsområder. Denne beslutningen har etter alt å dømme stor betydning for reformens måloppnåelse. Beslutningen ble imidlertid fattet på et seint tidspunkt i beslutningsprosessen og i strid med anbefalinger fra forskere og fagmyndigheter.

Ved større reformprosesser bør det som et minimum foreligge en identifikasjon og synliggjøring av de viktigste strategiske beslutningene som inngår i reformen. Et problem som må håndteres er imidlertid potensiell motstand mot slik synliggjøring. Slik motstand kan typisk oppstå som følge av mål om effektive beslutningsprosesser og næringsutvikling. De mekanismene som eksisterer i det norske forvaltningssystemet for å håndtere konsekvensene av slik motstand - Riksrevisjonen, Sivilombudsmannen og politisk ansvar gjennom demokratiske prosesser - kommer normalt inn på et sent tidspunkt og kan derfor være ineffektive for å hindre alvorlige negative økosystemvirkninger.

Studien gir ikke grunnlag for å avskrive prinsippet om økosystembasert forvaltning og føre var prinsippet som utopiske mål ved strategiske beslutninger. Prinsippene kan ha stor betydning for hvordan slike beslutningsprosesser fokuseres og struktureres. De kan også være viktige for vurderingen av om faktum og konsekvenser er tilstrekkelig utredet. Prinsippene er derfor av stor betydning for å ivareta sentrale og langsiktige miljøkonsekvenser for slike beslutninger, men det er fremdeles langt frem til effektiv gjennomføring i norsk forvaltning.

\section{Vedlegg}

Tabell 1: Fordeling av felleslokaliteter på produksjonsområder ${ }^{120}$

\begin{tabular}{|c|c|c|c|c|c|}
\hline $\begin{array}{l}\text { Prod } \\
\text { omr }\end{array}$ & $\begin{array}{l}\text { Lokaliteter } \\
\text { m/ } 2 \text { brukere }\end{array}$ & $\begin{array}{c}\text { Lok m/ } \\
3 \text { brukere }\end{array}$ & $\begin{array}{c}\text { Lok m/ } \\
4 \text { brukere }\end{array}$ & $\begin{array}{c}\text { Lok m/ } \\
5 \\
\text { brukere }\end{array}$ & Antall \\
\hline 3 & 23 & 6 & 14 & & 43 \\
\hline 8 & 14 & 15 & & & 29 \\
\hline 7 & 18 & 2 & & & 20 \\
\hline 6 & 17 & 1 & & & 18 \\
\hline 4 & 13 & 2 & & & 15 \\
\hline 10 & 12 & 1 & & & 13 \\
\hline 2 & 4 & & 1 & 7 & 12 \\
\hline 9 & 6 & & & & 6 \\
\hline 11 & 2 & 2 & 1 & & 5 \\
\hline 13 & 5 & & & & 5 \\
\hline 1 & 1 & 3 & & & 4 \\
\hline 5 & 2 & 1 & & & 3 \\
\hline Totalt & 117 & 33 & 16 & 7 & $173 / 18 \%$ \\
\hline
\end{tabular}

${ }^{120}$ Basert på statistikk fra Fiskeridirektoratet, se fn 8. 
Tabell 2: Vedtak om felles biomassetak, akvakulturdriftsforskriften $\S \S 48 a$ og $48 b^{121}$

\begin{tabular}{|l|l|l|l|l|l|l|l|}
\hline $\begin{array}{l}\text { Prod } \\
\text { omr }\end{array}$ & $\begin{array}{l}\text { Antall } \\
\text { vedtak }\end{array}$ & $\begin{array}{l}\text { Antall } \\
\text { tillatelser }\end{array}$ & $\begin{array}{l}\text { MTB } \mathbf{( 1 0 0 0} \\
\text { tonn) }\end{array}$ & $\begin{array}{l}\text { Felles med } \\
\text { prod omr }\end{array}$ & $\begin{array}{l}\text { Miljø- } \\
\text { effekt } \\
\text { ut }\end{array}$ & $\begin{array}{l}\text { Miljø- } \\
\text { effekt } \\
\text { inn }\end{array}$ & $\begin{array}{l}\text { Samlet } \\
\text { miljø- } \\
\text { effekt }\end{array}$ \\
\hline 1 & 1 & $20(87 \%)$ & $16,5(85 \%)$ & 2,3 & +2 & -1 & +1 Grønn \\
\hline 2 & 2 & $24(50 \%)$ & $18,7(44 \%)$ & 1,3 & 0 & -2 & -2 Gul \\
\hline 3 & 9 & $71(66 \%)$ & $60,9(70 \%)$ & $1,2,4$ & +1 & -3 & -2 Rød \\
\hline 4 & 8 & $76(57 \%)$ & $59,8(58 \%)$ & $3,5,6$ & +1 & -3 & -2 Rød \\
\hline 5 & 3 & $54(82 \%)$ & $42,1(82 \%)$ & $4,6,7$ & +3 & -3 & 0 Gul \\
\hline 6 & 4 & $130(82 \%)$ & $103,7(82 \%)$ & $4,5,7$ & +3 & -3 & 0 Gul \\
\hline 7 & 5 & $42(63 \%)$ & $32,5(61 \%)$ & $5,6,8,9$ & +1 & -2 & -1 Grønn \\
\hline 8 & 5 & $34(37 \%)$ & $25,7(35 \%)$ & 7,9 & +1 & -2 & -1 Grønn \\
\hline 9 & 5 & $33(37 \%)$ & $25,7(38 \%)$ & $7,8,10,11$ & +1 & -2 & -1 Grønn \\
\hline 10 & 5 & $34(55 \%)$ & $33,1(54 \%)$ & $9,11,12,13$ & +1 & -2 & -1 Grønn \\
\hline 11 & 6 & $35(73 \%)$ & $34,5(72 \%)$ & $10,12,13$ & +2 & -2 & 0 Grønn \\
\hline 12 & 2 & $24(31 \%)$ & $24,5(32 \%)$ & $10,11,13$ & +1 & -1 & 0 Grønn \\
\hline 13 & 2 & $16(100 \%)$ & $17,4(100 \%)$ & $10,11,12$ & +3 & -2 & +1 Grønn \\
\hline Samlet: $\mathbf{2 5}$ & $\mathbf{5 9 3}(\mathbf{6 0} \%)$ & $\mathbf{4 9 5 , 2 ( 5 9 \% )}$ & & $+\mathbf{2 0}$ & $\mathbf{- 2 8}$ & $-\mathbf{- 8}$ \\
\hline
\end{tabular}

\footnotetext{
${ }^{121}$ Tabellen gir en oversikt over graden av fleksibilitet til å flytte produksjon $u t$ av produksjonsområdene $\mathrm{i}$ kolonne 2-5. Produksjonsmengden som kan flyttes inn $i$ produksjonsområdene varierte mellom 11,5 og 79,2 tusen tonn. Basert på dette samt data om oppdretternes tilgang til ledig kapasitet i lokaliteter og klassifiseringen av produksjonsområdene, er det foretatt en vurdering av miljøeffekten av fleksibiliteten til å flytte produksjon ut av og inn i de enkelte områdene. Fleksibilitet $u t$ av et område er vurdert på en skala fra 0 til +3 og forutsetter at slik flytting vil være miljømessig positiv. Motsvarende er fleksibilitet til å flytte inn $i$ et område vurdert på en skala fra 0 til -3 , under forutsetning av at slik flytting vil være miljømessig negativ.
} 